\title{
$V-M Y$
}

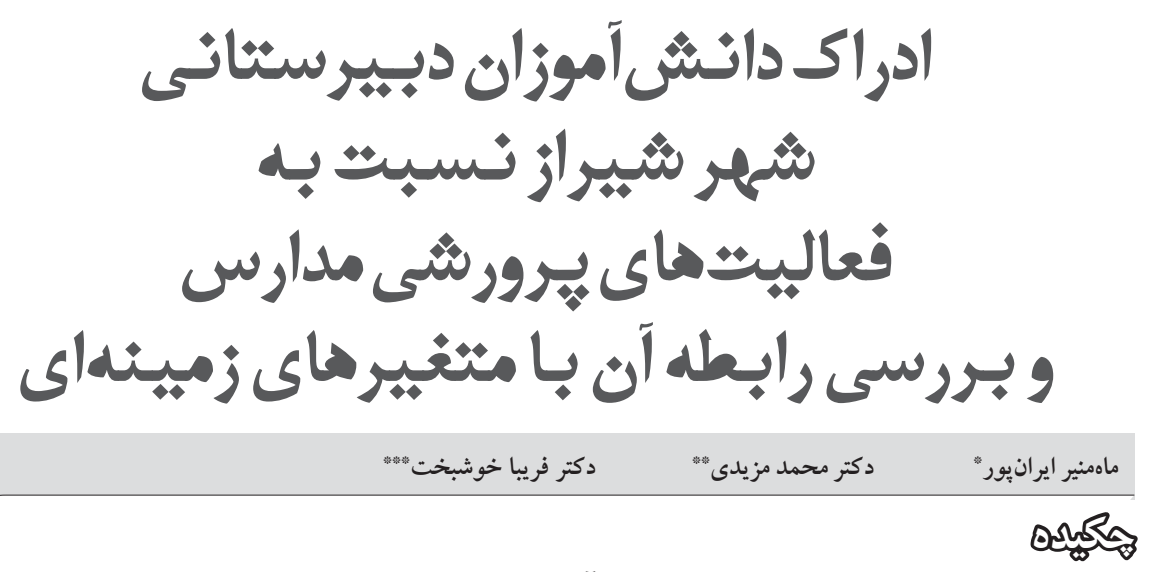

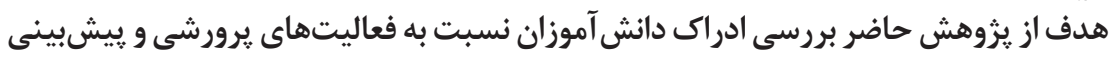

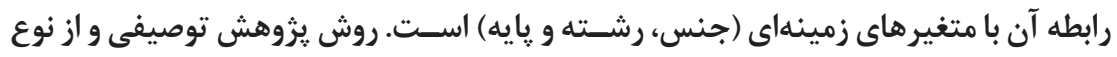

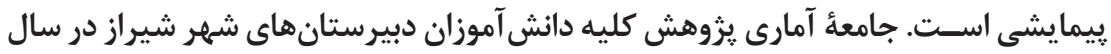

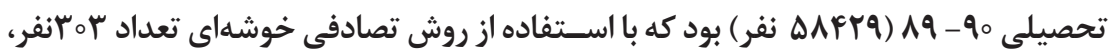

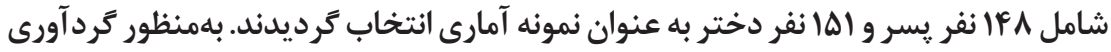

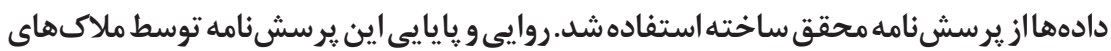

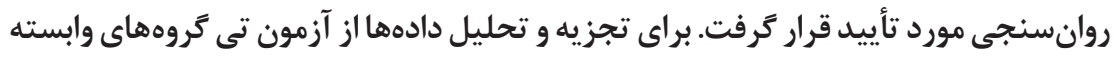

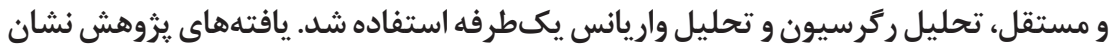

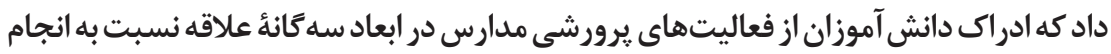

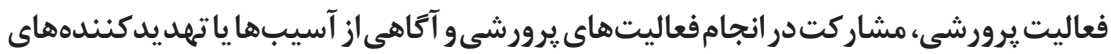

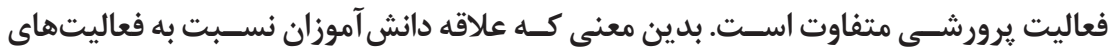

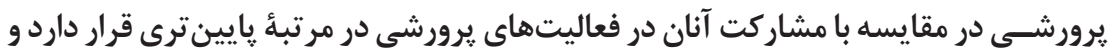

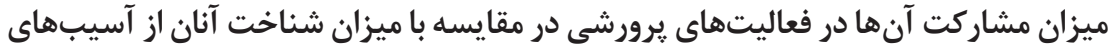

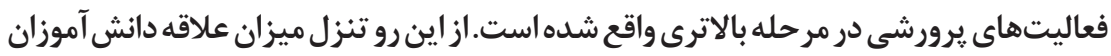

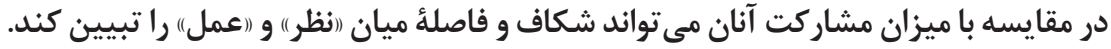

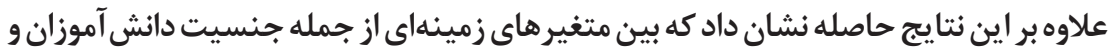

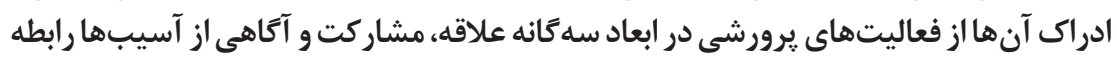

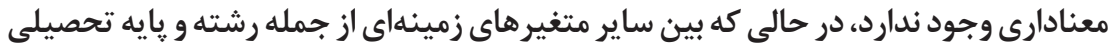

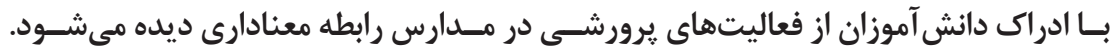

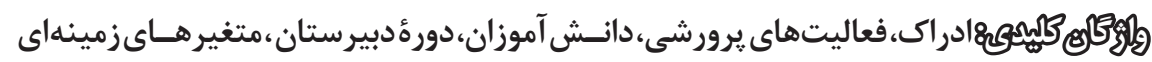

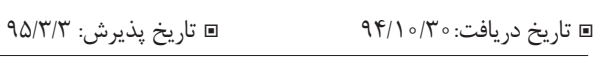

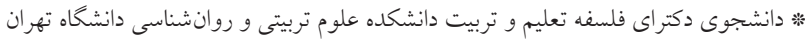

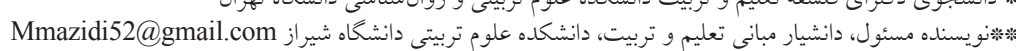

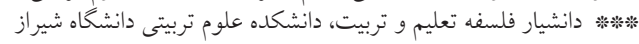


آموزش و برورش از مهمترين نهادهاى اجتماعى است و در مقايسه با ديخر نهادها

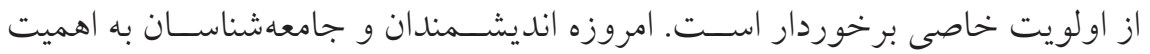

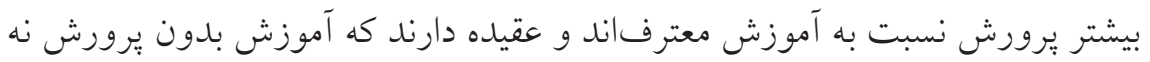

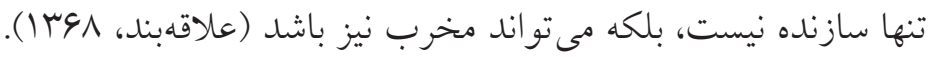

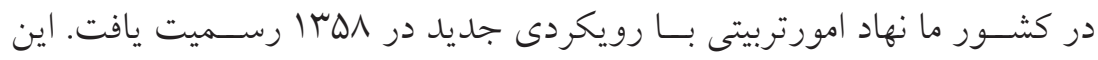

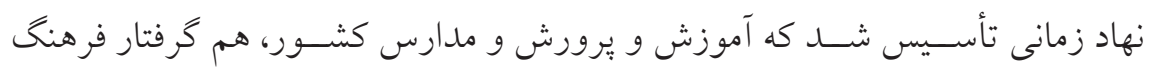

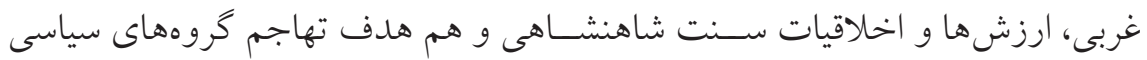
شـده بود. نيت مؤسسين اين نهاد يس از انقلاب حفظ دست آوردهاى انقلاب، ترويج

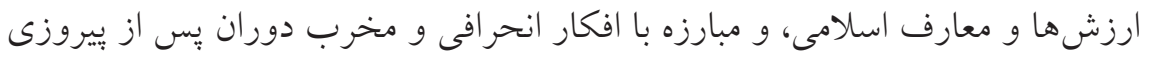

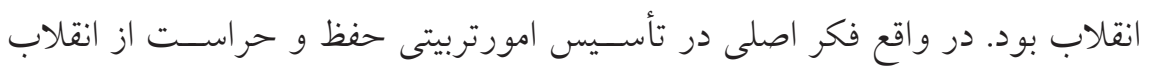

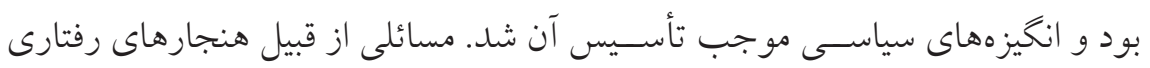

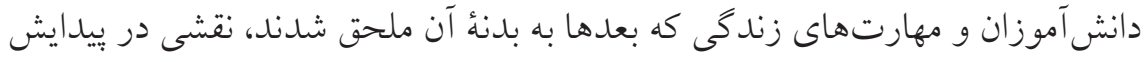

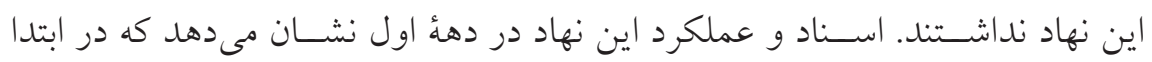

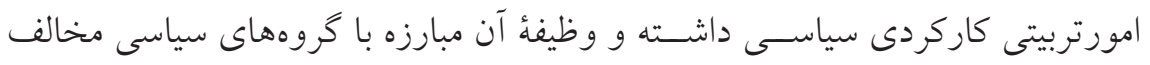

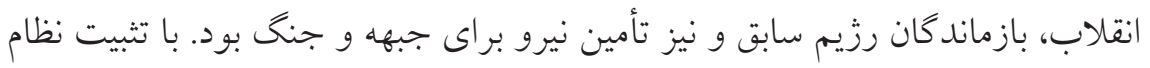

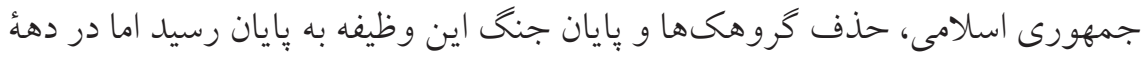

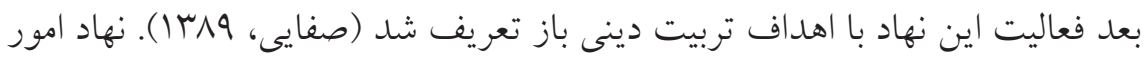

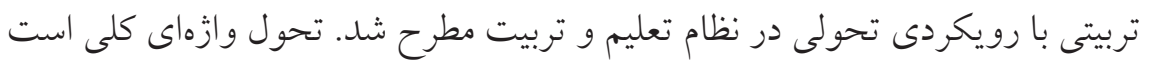
كه ساز و كار را بايد مطابق با مقتضيات زمان و مكان در نظر داثته باشيم. فعاليتهاى درون يرورشسى مجموعه فعاليتهايى اسـت كه در اكثر موارد، در ساعات درسى مدرسه با هدايت و برنامهريزى حوزةه معاونت برورشى و توسط مربيان تربيتى مدرسه، با هدف

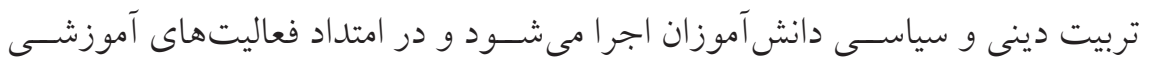

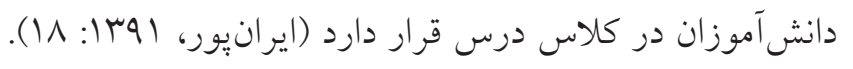

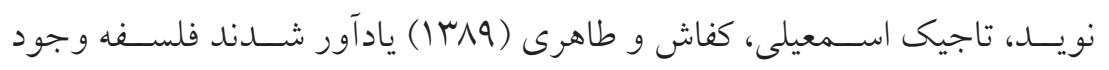

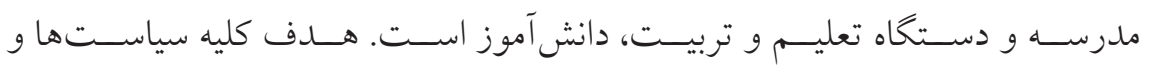

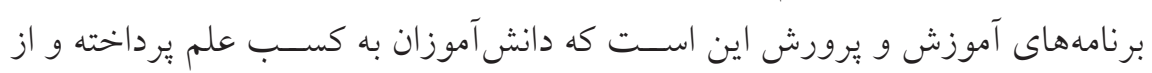




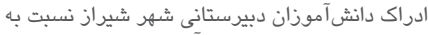

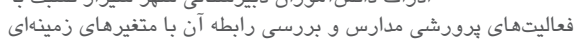

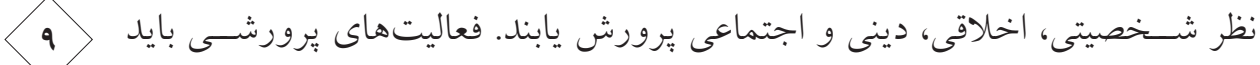

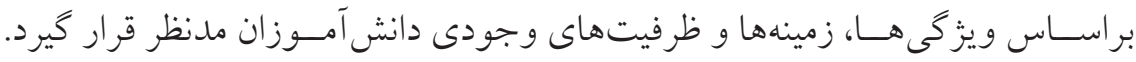
توجسه به ظرفيتها و زمينهاى مذكور از دو جهت حائز اهميت اســت يكى اين كه ونه

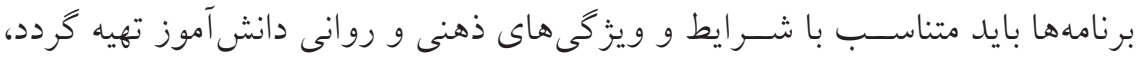

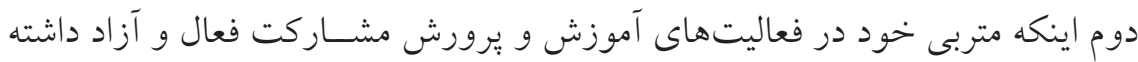

خوشـبختنانه در اسناد بالادسـتى وزارت آموزش و يرورش از جمله مبانى نظرى

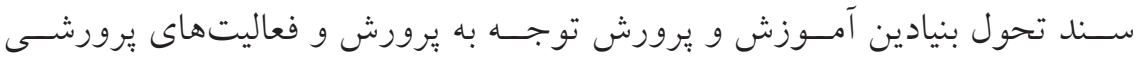

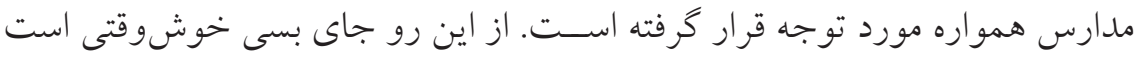

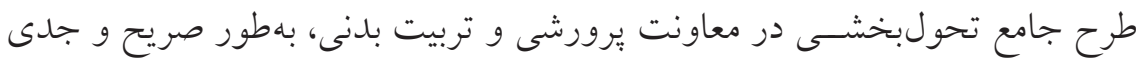

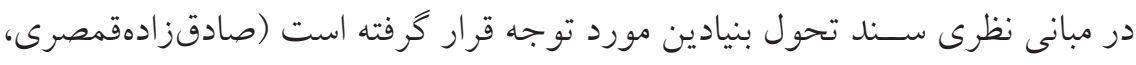

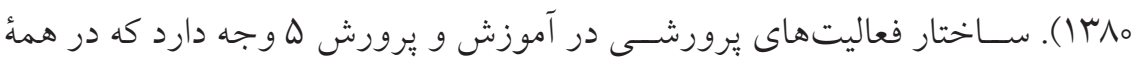

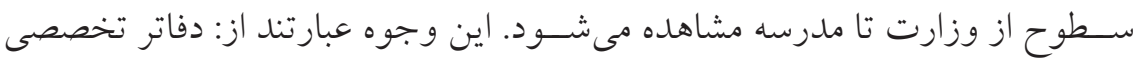

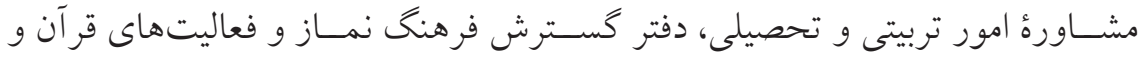

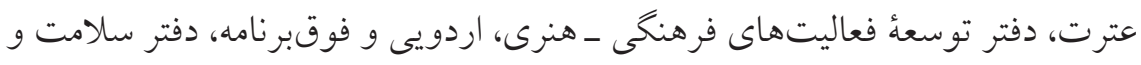

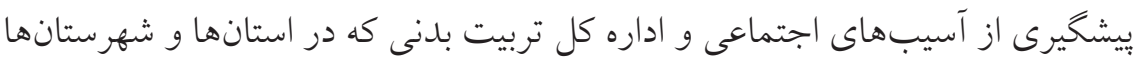

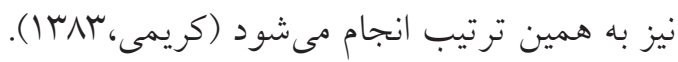

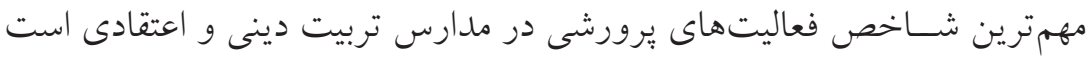

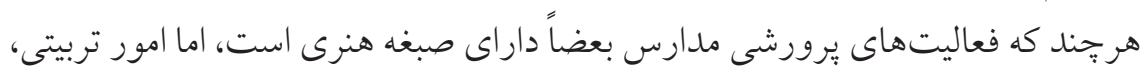

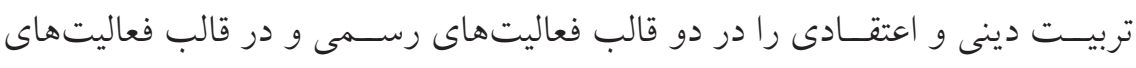

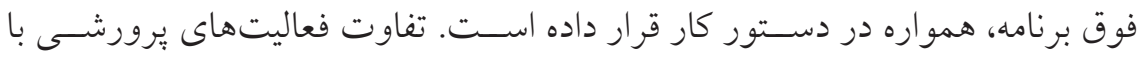

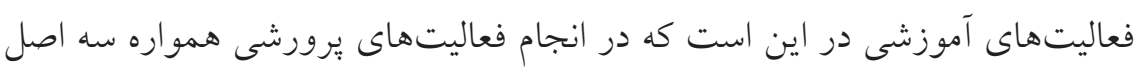

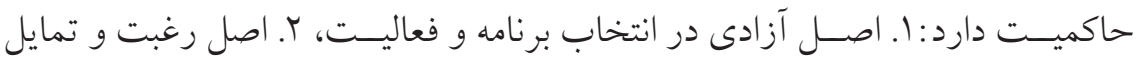
در انجام فعاليتها و ب. اصل خودانخيختخى. يعنى فعاليتهاى برورشسى بايد با نياز

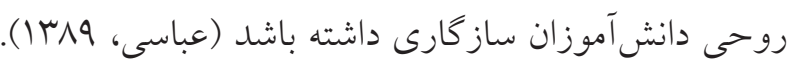

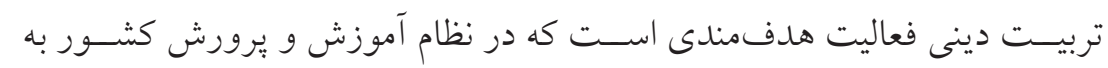

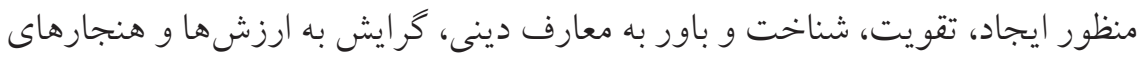


دينى، التزام عملى به احكام و دسـتورات دينى طراحى شده است(صادقزادهقمصرى،

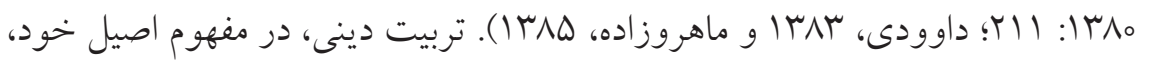

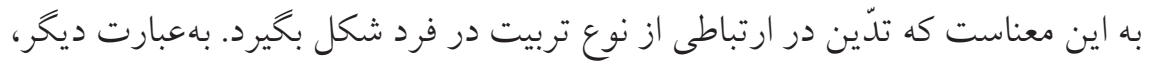

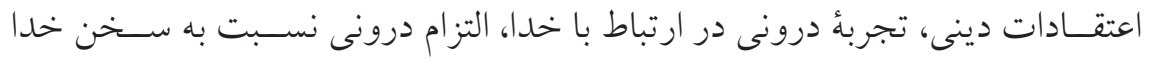

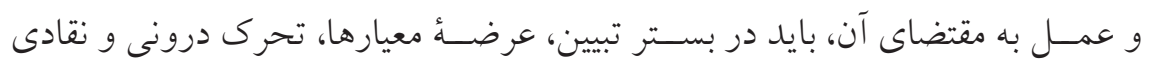

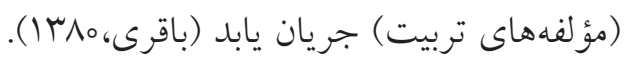

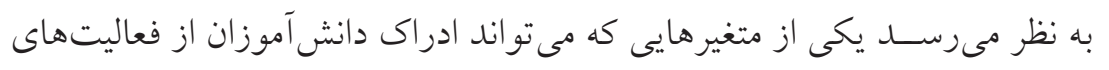

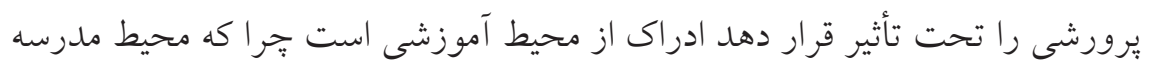

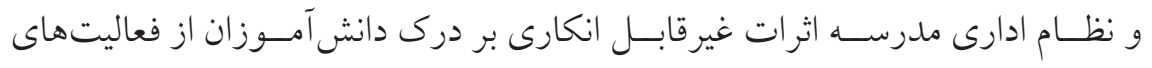

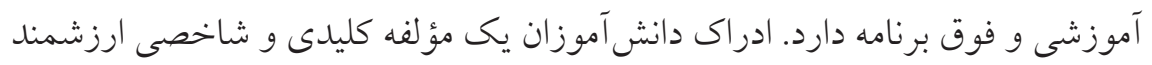

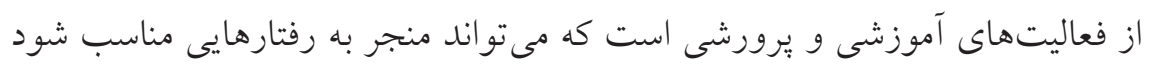

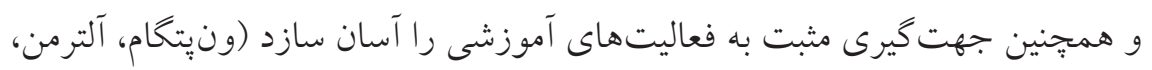

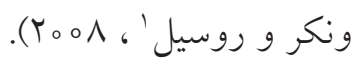

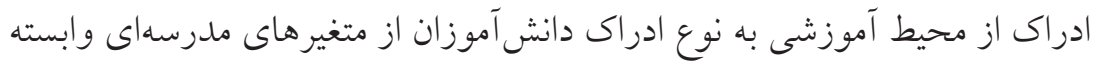

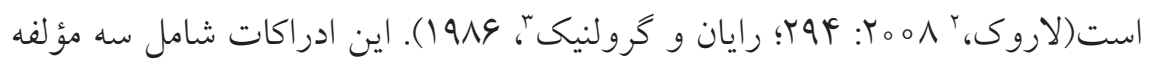

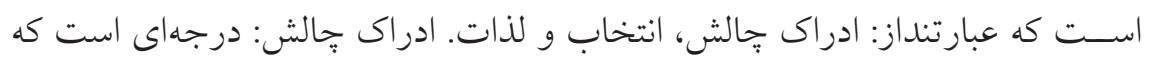

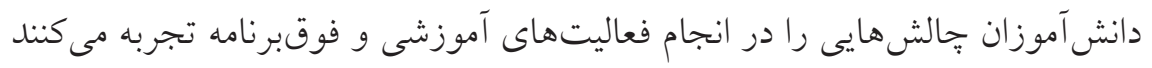

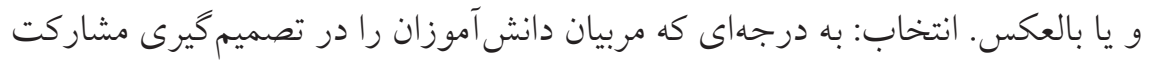

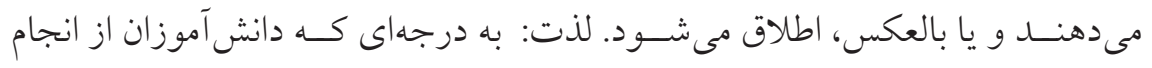

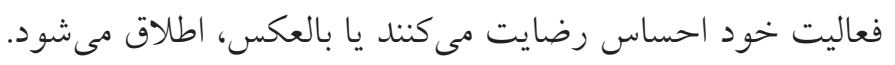

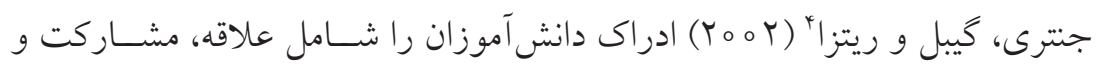

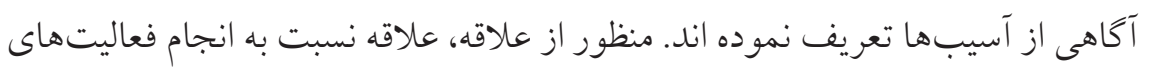

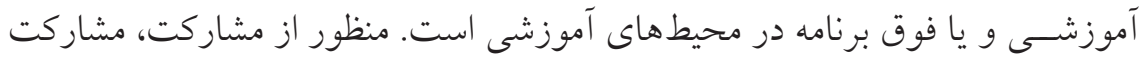

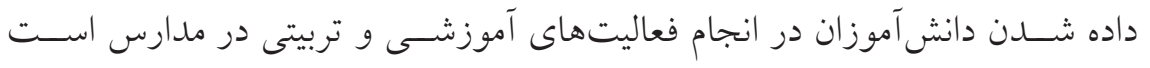

1 Van Petegem, Aelterman, Van Keer \& Rosseel

2 LaRocque

3 Ryan \& Grolnick

4 Gentry, Gable \& Rizza 


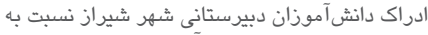

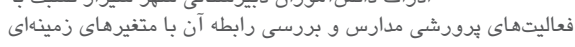

و منظور از آكاهى از آسـيبها، آكاهى از آسـيبـها يــا تهديدكنندهاى فعاليتهاى

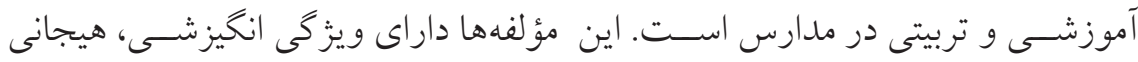
هستند و شايد بتو انند بيشبين تحول مثبت در نظامهاى آموزشى باشند. در اين مطالعه

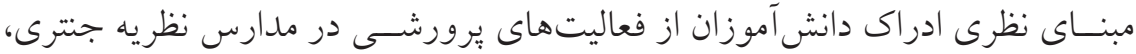

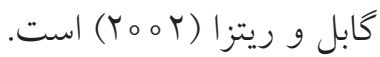

يزّوهشهاى متعددى در اين زمينه به بررسسى عوامل مرتبط با تحول تربيتى در نظام

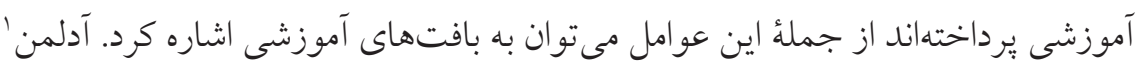

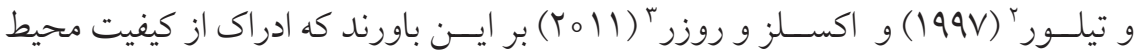

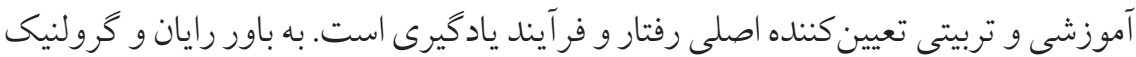

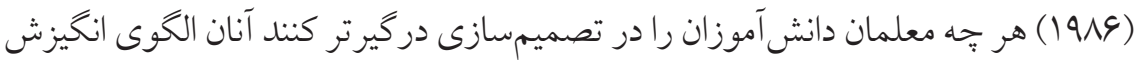

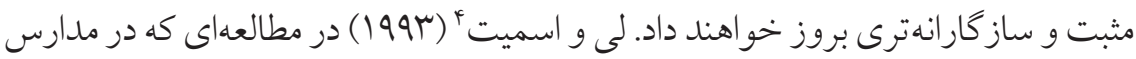

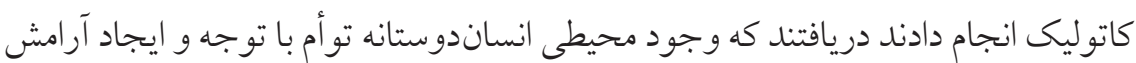

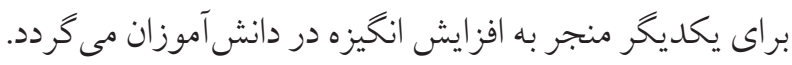

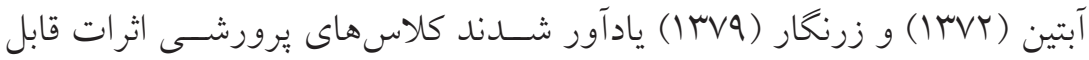

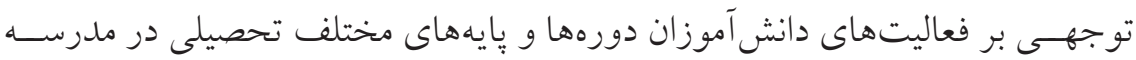

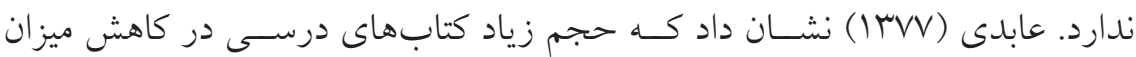

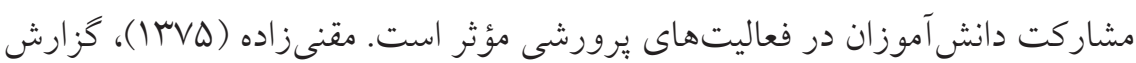

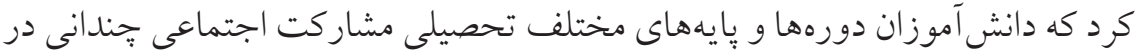

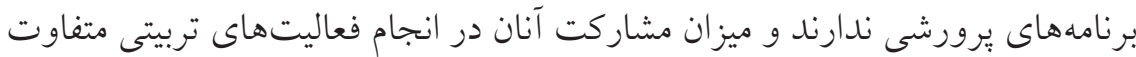

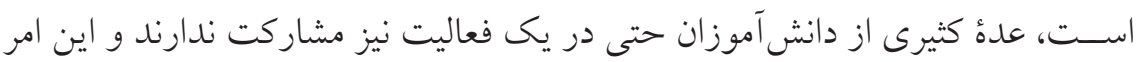

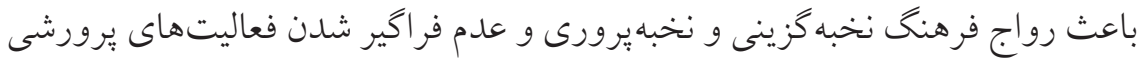

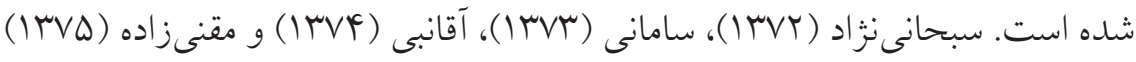
عدم رابطه بين ميزان مشاركت مدير، معلمان و نيروهاى آموزشى با مربى يرورشى در

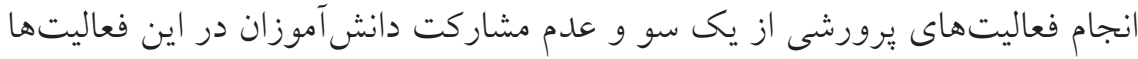

1 Adelman

2 Taylor

3 Eccles \& Roeser

4 Lee \& Smith 
را، از سوى ديخر مورد تأييد قرار دادهاند. بختيارنصر آبادى و نوروزى (rیץ|) يادآور

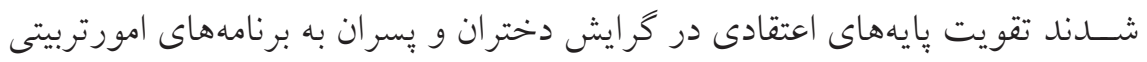

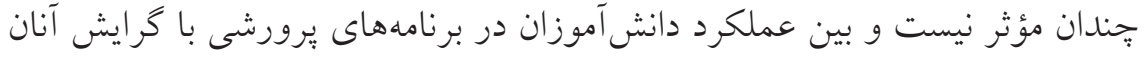

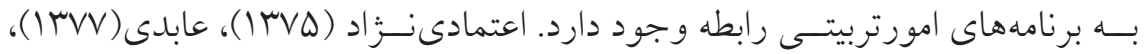

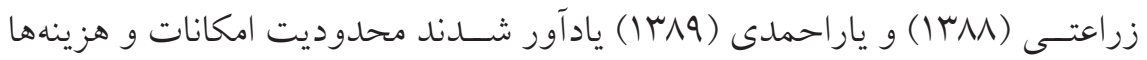

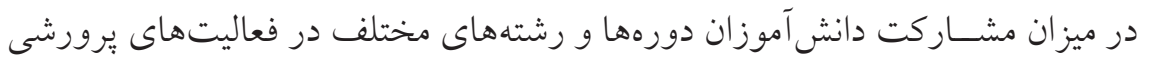

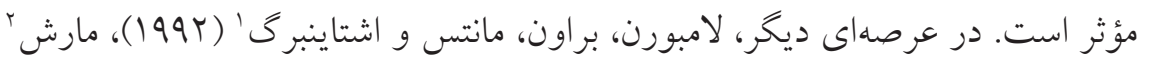

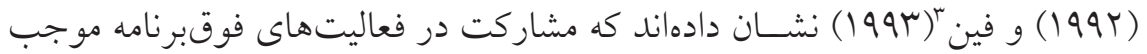
افزايش وابسـتخى، تعامل و تعهل بيشـتر دانش آموزان نسبت به مدرسه و باعث ايجاد

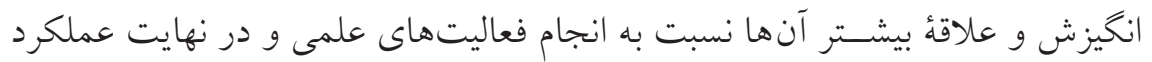
علمى بهتر مى گردد.

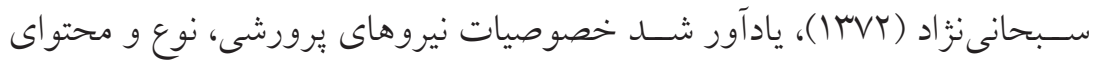

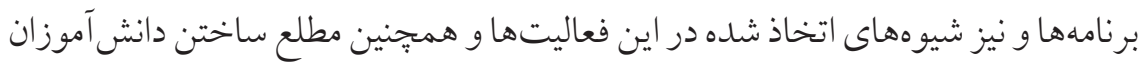
در دورههاى مختلف ابتدايى، راهنمايى، متوسطه و همينطور بايههاى مختلف از اهداف

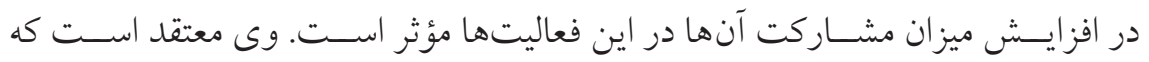

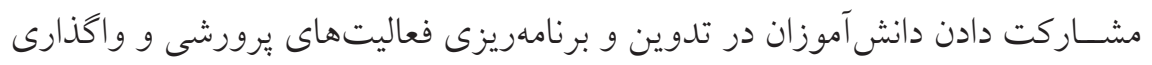
مسئوليت به آنان در افزايش شركت آنها در اين فعاليتها مؤثر است. عابدى (ITVV) و اعتمادىنزاد(IVVDV) معتقدند كه ميزان تخصص نيروهاى يرورشسى با ميزان موفقيت

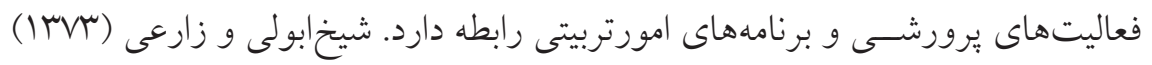

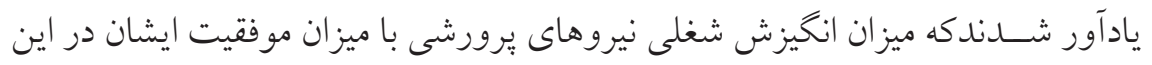

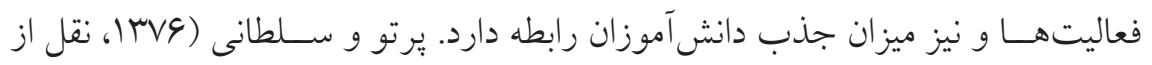

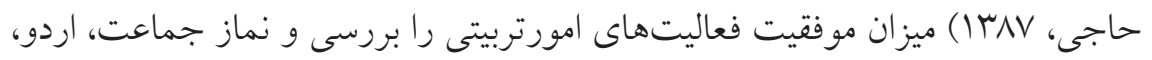

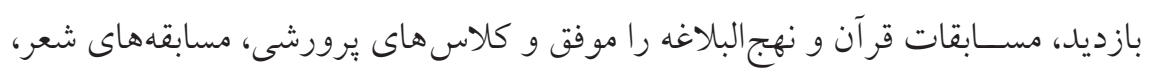

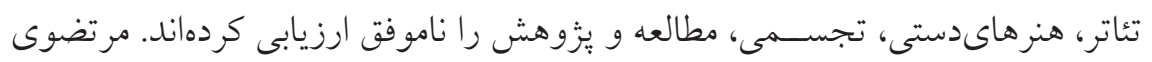

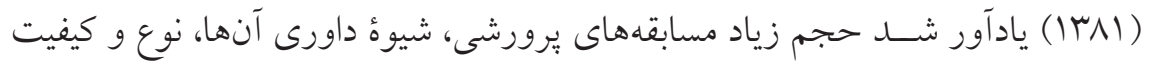

1 - Lamborn, Brown, Mounts \& Steinberg 2 - Marsh 


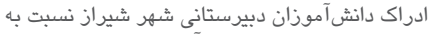

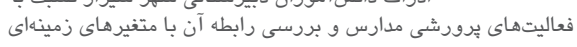

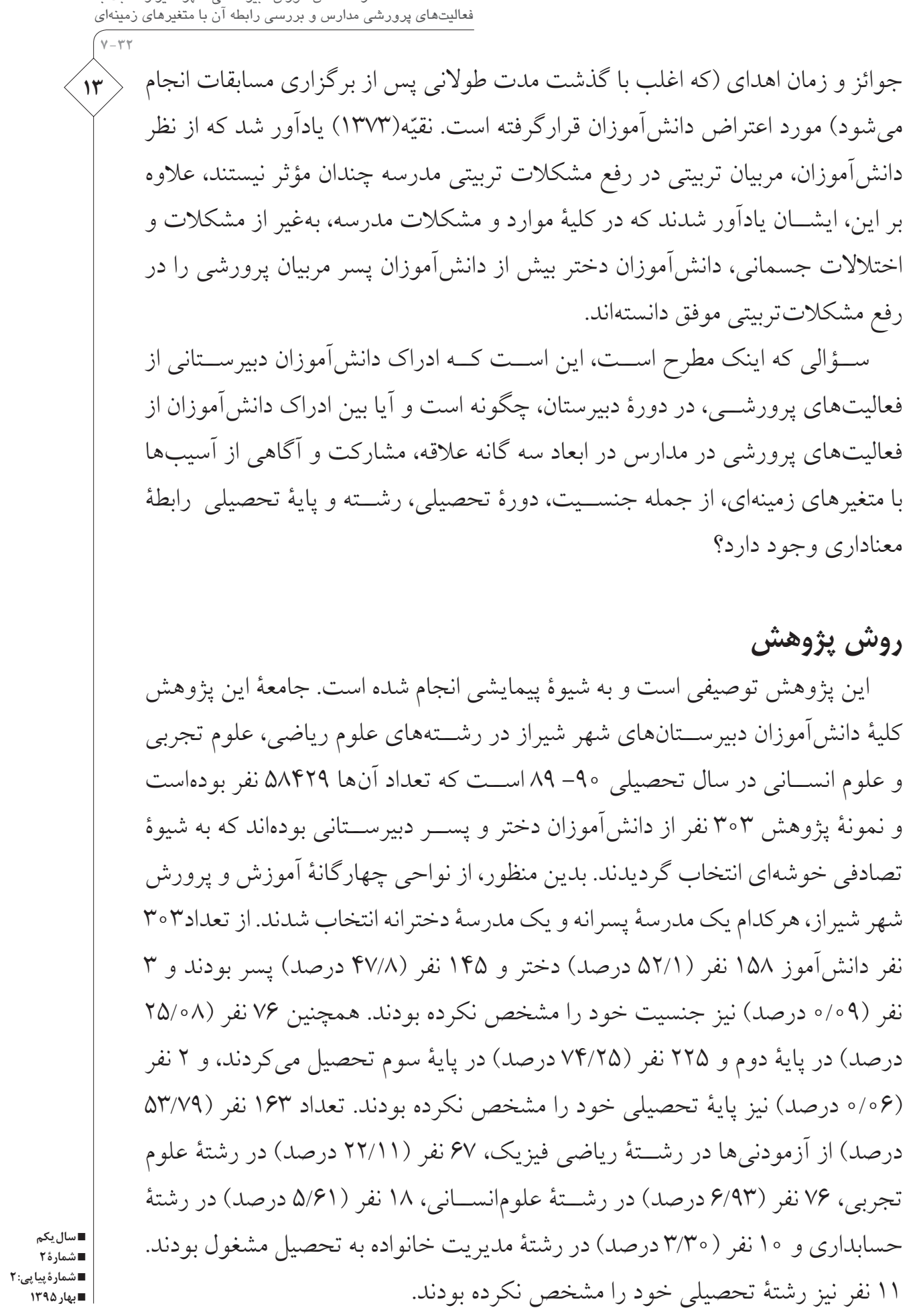




\section{فصلنامه مسائل كاربردى تعليم و تربيت اسلامى \\ ابزار جمعآورى اطلاعات}

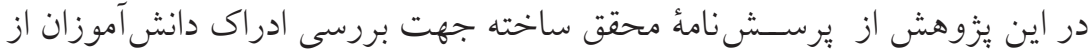

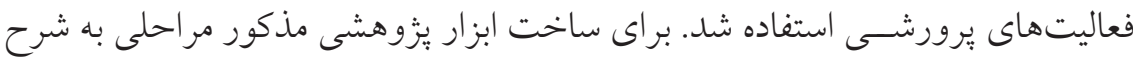

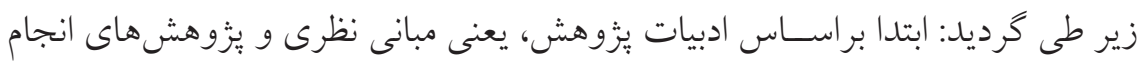

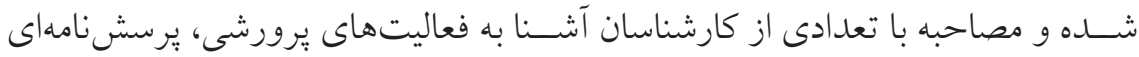

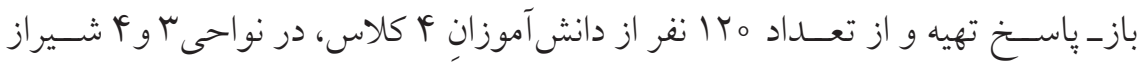

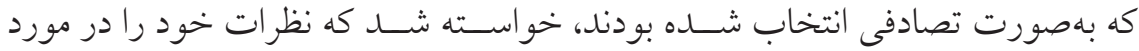

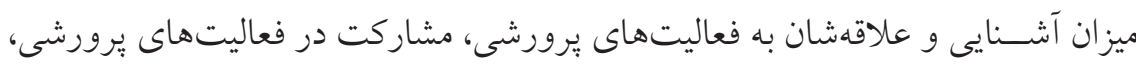

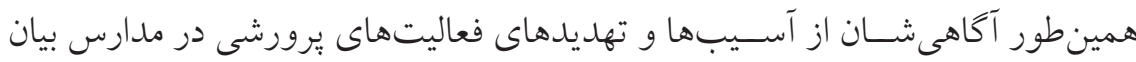

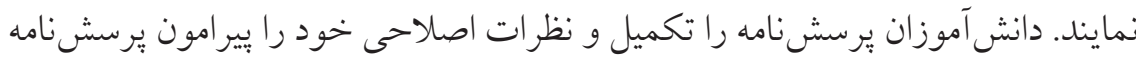

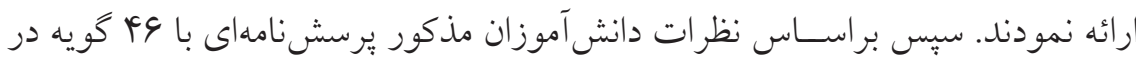

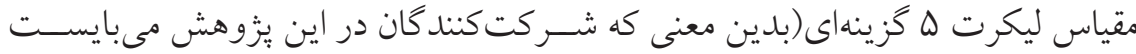

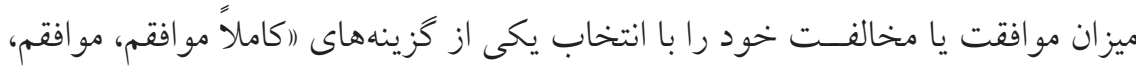

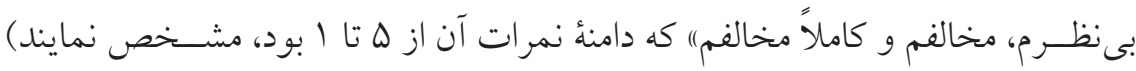

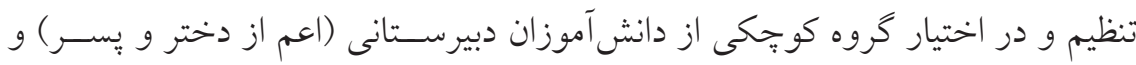

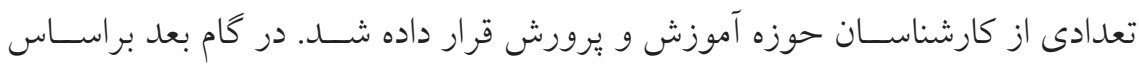
نظرات اين دو كروه سؤالات مشابه حذف كرديد.

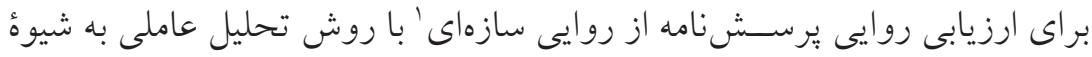

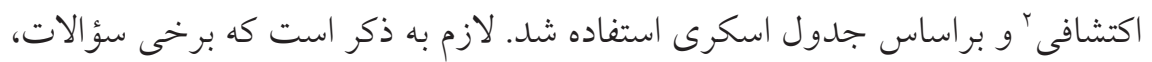

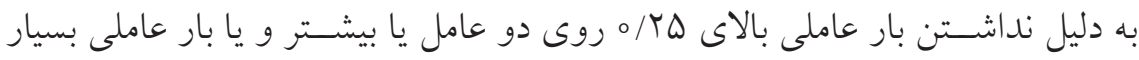

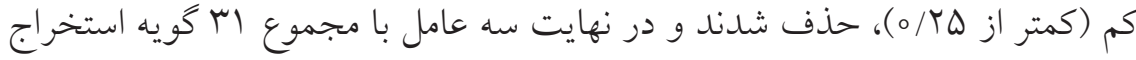

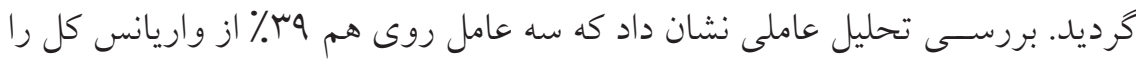

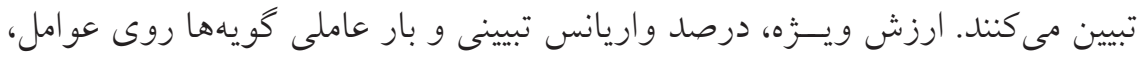

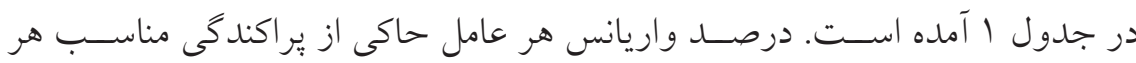

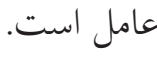




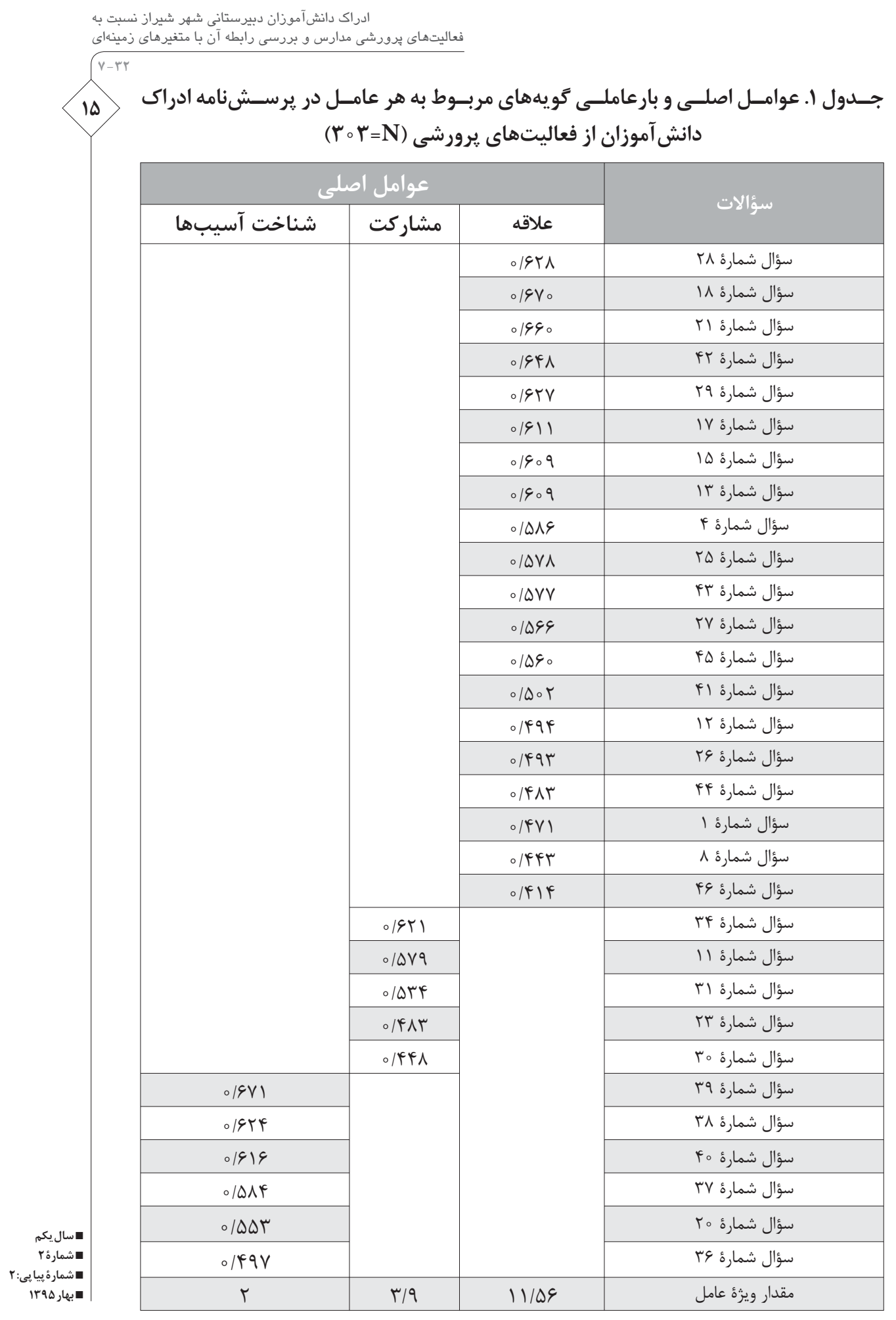




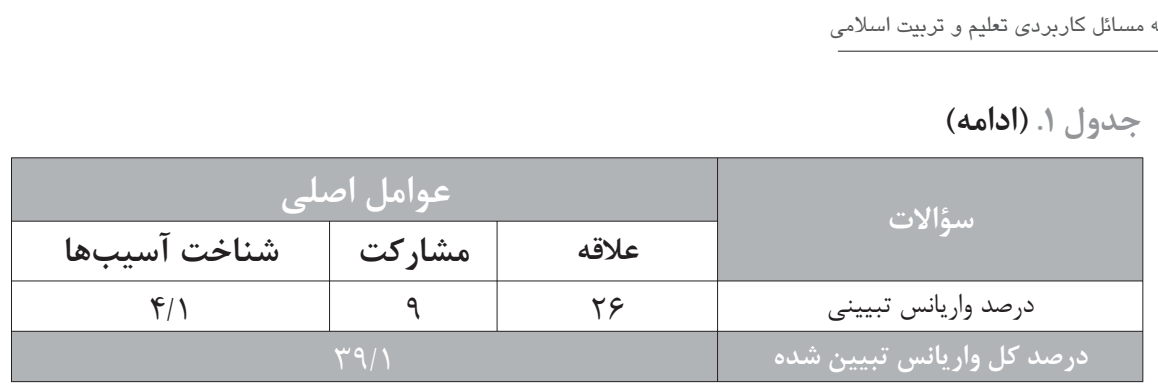

جهت آكاهى از شاخص كفايت نمونهبردارى از آزمون كرويت بارتلت استفاده شد

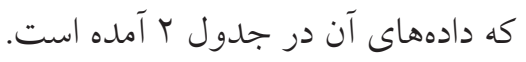
جدول r. آزمون كرويت بارتلت

\begin{tabular}{|c|c|c|}
\hline سطح معنادارى & بارتلت & $\mathrm{KMO}$ \\
\hline $0 / 0001$ & $\Gamma \Lambda_{0} \mid / \Gamma$ & ०/A9 \\
\hline
\end{tabular}

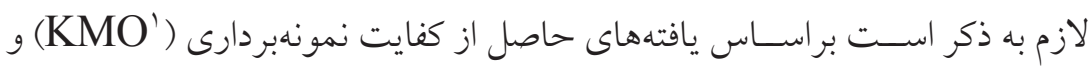

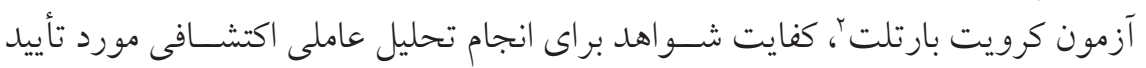

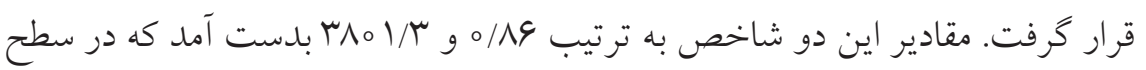

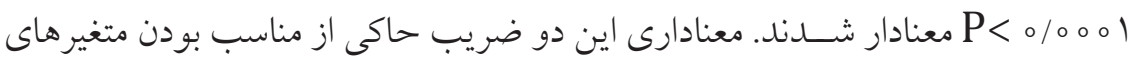
وارد شده براى تحليل عاملى است.

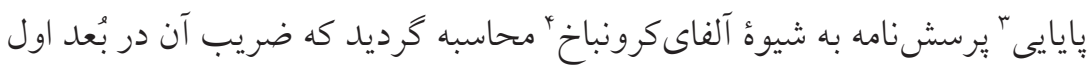

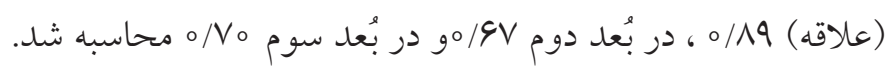

\section{يافتهها}

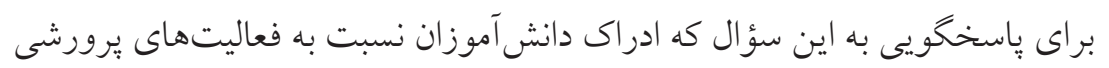

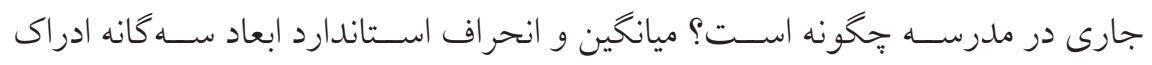

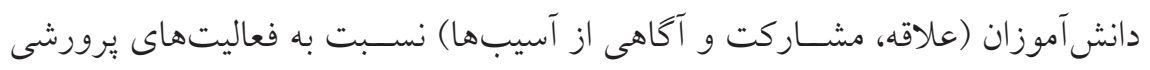

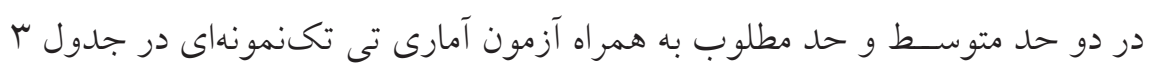

$$
\text { كزارش شده است. }
$$

1. Kaiser-Meyer-Olkin

2. Bartlett's test of sphericity

3. Reliability

4. Cronbach's alpha 


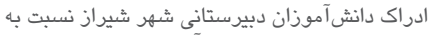

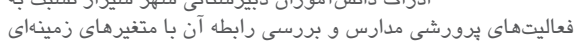

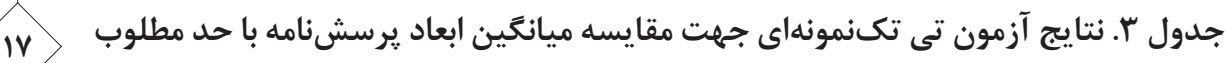
و حد متوسط

\begin{tabular}{|c|c|c|c|c|c|c|}
\hline \multicolumn{2}{|c|}{ حد مطلوب(f) } & \multicolumn{2}{|c|}{ حد متوسط (广ّ) } & \multirow{2}{*}{ استاندارو انح } & \multirow{2}{*}{ ميانَين } & \multirow{2}{*}{ متغير } \\
\hline سطح معنادارى & $\mathbf{t}$ & سطح معنادارى & $\mathbf{t}$ & & & \\
\hline $0 / 0001$ & IV/VT & $0 / 001$ & 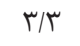 & $\circ / V r$ & $r / 19$ & علاقه \\
\hline $0 / 0001$ & $\Delta / M F$ & 010001 & $19 / V 9$ & o/VF & r/VG & مشاركت \\
\hline $0 / 0001$ & $N / \Delta V$ & 010001 & $|f /| \mid$ & $\circ / V G$ & $r / 91$ & شناخت \\
\hline
\end{tabular}

تحليـل دادههاى حاصل از جدول ب حاكى از اين اسـت كــه ادراك دانش آموزان

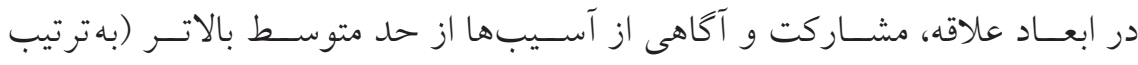

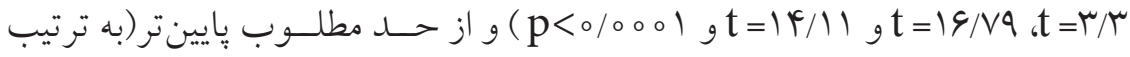

$$
\text { ( } \mathrm{p}<0 / 000), \mathrm{t}=\Lambda / \Delta V, \mathrm{t}=\Delta / \mu \mathrm{r} ، \mathrm{t}=\mathrm{lV} / \mathrm{VT}
$$

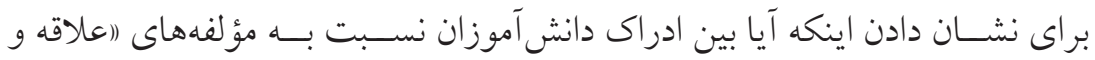

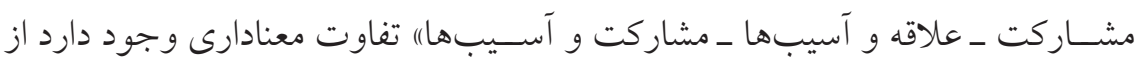

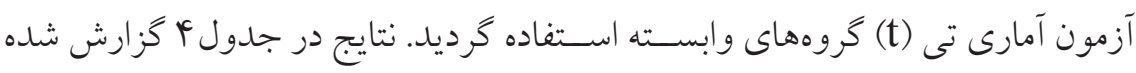
است.

جدول F. نتايج آزمون تى وابسـته بين ادراكات دانش آموزان پِيرامون فعاليتهاى يرورشـى در مدارس ادرات دانش

\begin{tabular}{|c|c|c|}
\hline معنادارى & t & متغير \\
\hline \multirow{2}{*}{010001} & \multirow{2}{*}{$1 Y / 19$} & علاقه \\
\hline & & مشاركت \\
\hline \multirow{2}{*}{$0 / 0001$} & \multirow{2}{*}{$9 \mid 9 T$} & علاقه \\
\hline & & شناخت آسيب ها \\
\hline \multirow{2}{*}{01009} & \multirow{2}{*}{$r / V \Delta$} & مشاركت \\
\hline & & شناخت آسيب ها \\
\hline
\end{tabular}


تحليل دادههاى حاصل از جدول \& جاكى از اين اسـت كه بين ادراك دانشآموزان

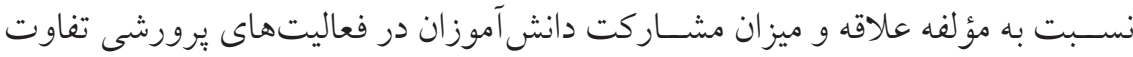

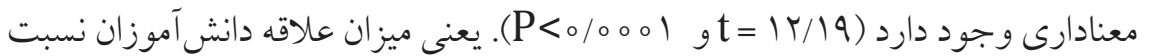
به فعاليتهاى برورشى در مقايسه با ميزان مشاركت آنها در فعاليتهاى يرورشى بهطور

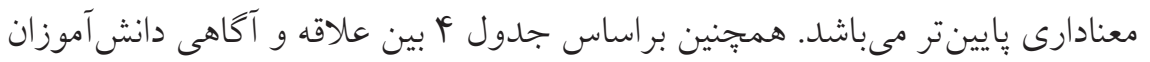
در مورد فعاليتهاى برورشسى و ميزان شـناخت آسـيبـهاى موجود در اين فعاليتها

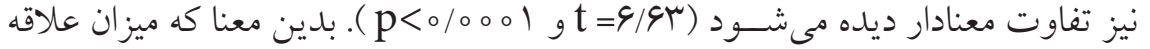

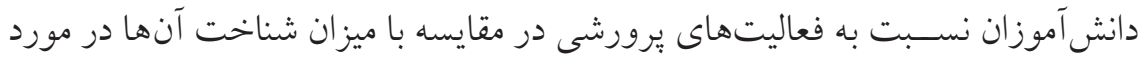
آسـيبهاى موجود در فعاليتهاى برورشسى بهطور معنادارى بايينتر است. علاوه بر بر برونس

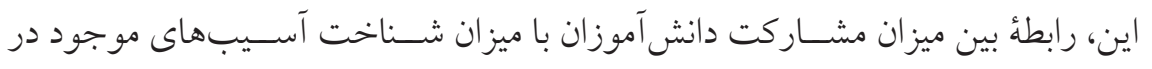

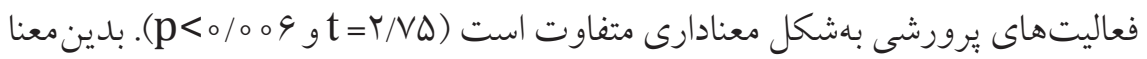

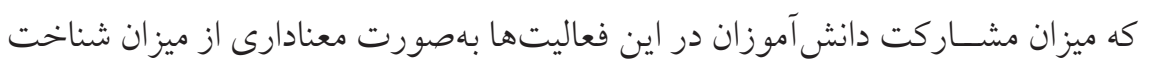

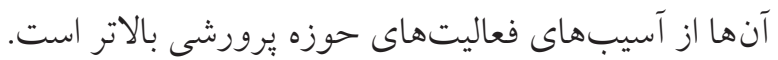

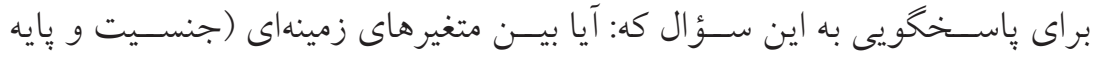

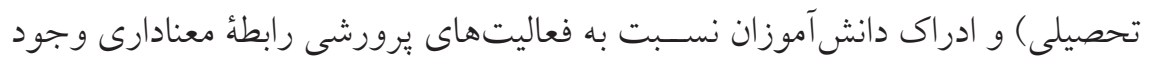

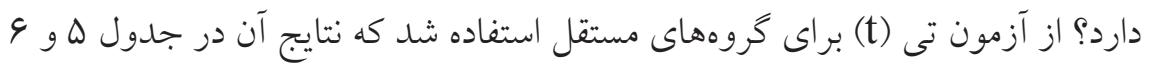

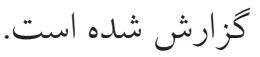

جدول ه. نتايج آزمون تى مسـتقل بين متغير جنســيت و ادراكـات دانسـشآموزان پِيرامون

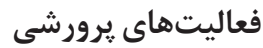

\begin{tabular}{|c|c|c|c|c|c|}
\hline سطح معنادارى & $\mathrm{t}$ & انحراف استاندارد & ميانَكين & جنسيت & متغير \\
\hline \multirow{2}{*}{ O/IVT } & \multirow{2}{*}{ - /NIa } & $\mid Q / F$ & $g q$ & دختر & \multirow{2}{*}{ علاقه } \\
\hline & & $\mid r / V$ & $s \pi / r$ & پֶر & \\
\hline \multirow{2}{*}{.$/ V F A$} & \multirow{2}{*}{$r / l F$} & $\Gamma / \Lambda$ & $19 / \pi$ & د ختر & \multirow{2}{*}{ مشاركت } \\
\hline & & $\Gamma / \Lambda$ & $\mid N / r$ & يسر & \\
\hline \multirow{2}{*}{ O/TVK } & \multirow{2}{*}{$1 / 1$} & $F / V$ & $r / / Q$ & دختر & \multirow{2}{*}{ شناخت } \\
\hline & & $r / T$ & $r T / r_{0}$ & هِر & \\
\hline
\end{tabular}




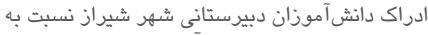

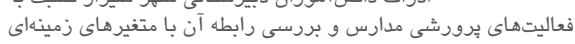

تحليل دادههاى جدول ه حاكى از اين است كه در ابعاد سه گانه علاقه، مشاركت و

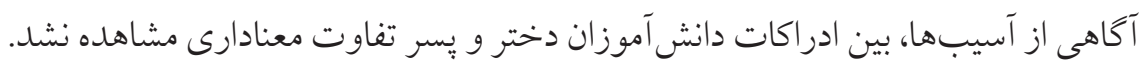

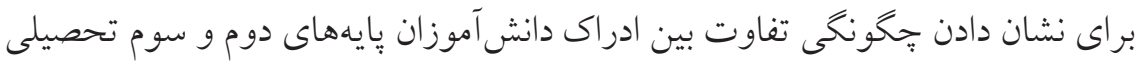

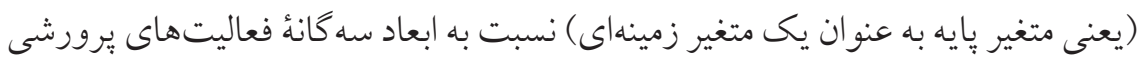

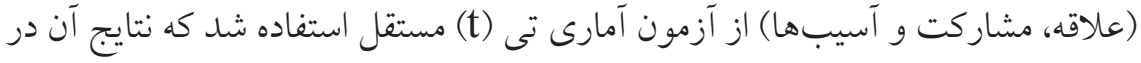
جدول و كزارش شده است.

جدول و. نتايج آزمون تى مسـتقل بين متغيــر بايهتحصيلى و ادراكات دانش آموزان بيرامون

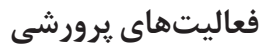

\begin{tabular}{|c|c|c|c|c|c|}
\hline سطح معنادارى & $\mathrm{t}$ & انحراف استاندارد & ميانگين & بائه تحصيلى & متغير \\
\hline \multirow{2}{*}{ o/9vq } & \multirow{2}{*}{$F / q \mu$} & $\mid r / V$ & $V_{0} / 9 \mathrm{~V}$ & 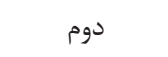 & \multirow{2}{*}{ علاقه } \\
\hline & & $\mid F / 0 Y$ & $G \circ / V V$ & سوم - & \\
\hline \multirow{2}{*}{ o/DFF } & \multirow{2}{*}{$-0 / 90$} & $r / 9$ & $\mid N / F V$ & دوم & \multirow{2}{*}{ مشاركت } \\
\hline & & r/VF & 19 & 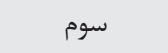 & \\
\hline \multirow{2}{*}{ o/VVF } & \multirow{2}{*}{$-T / F$} & F/VA & To/gr & دوم & \multirow{2}{*}{ آسيباختا } \\
\hline & & $F / \Gamma_{0}$ & $T Y / I I$ & سوم & \\
\hline
\end{tabular}

تحليل دادههاى جدول و حاكى از اين اسـت كه بين ادراك دانش آموزان بايههاى

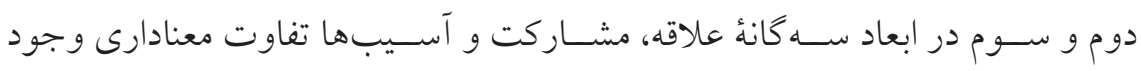

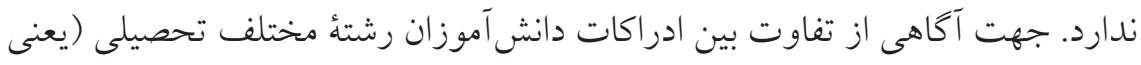
متغير رشته به عنوان يك متغير زمينهاى) نسبت به ابعاد سه كانه، فعاليتهاى يرورشى آنى

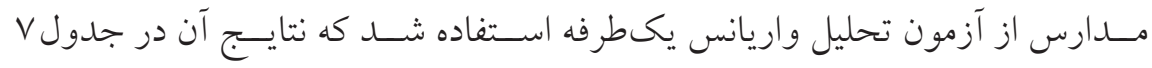




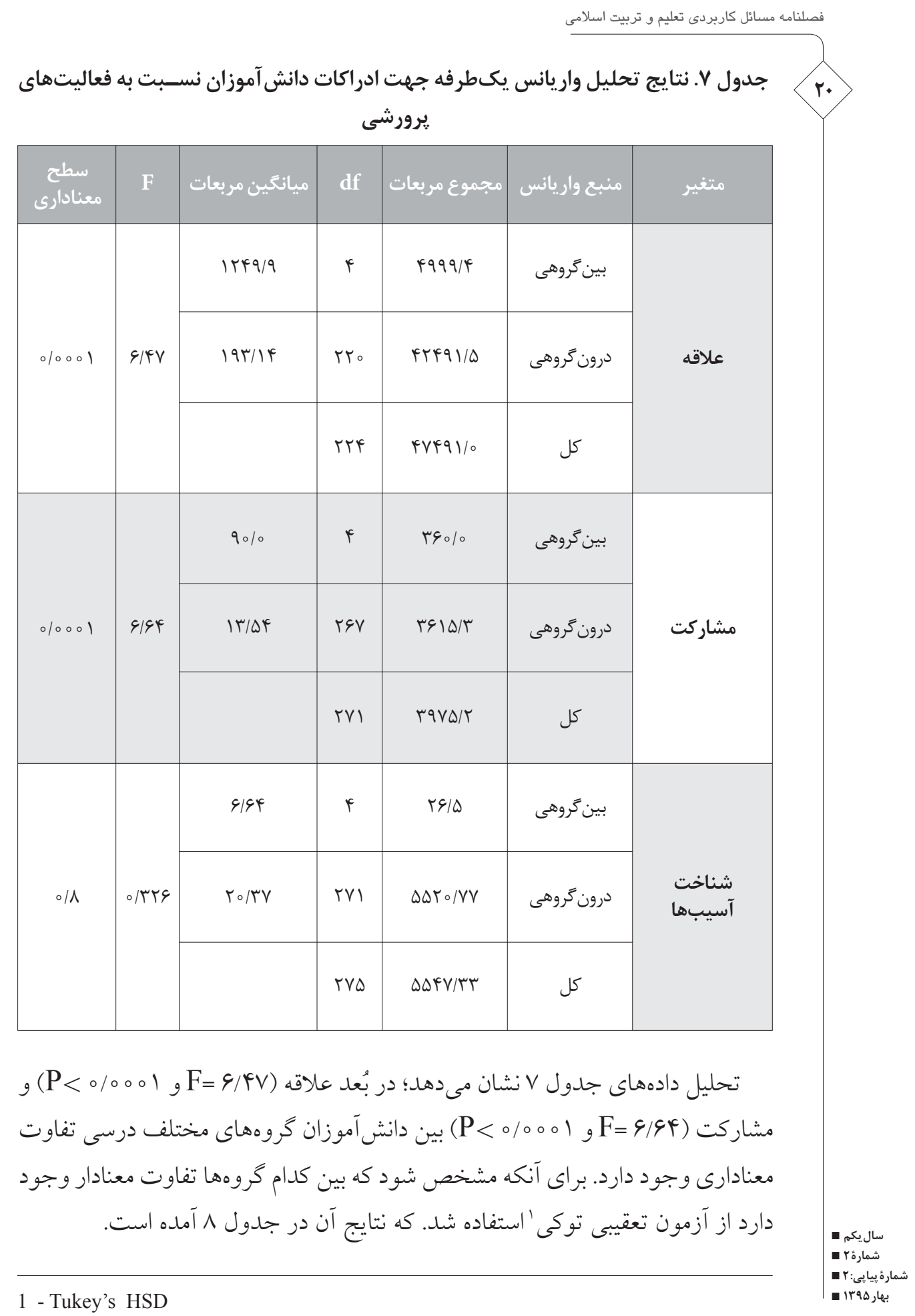




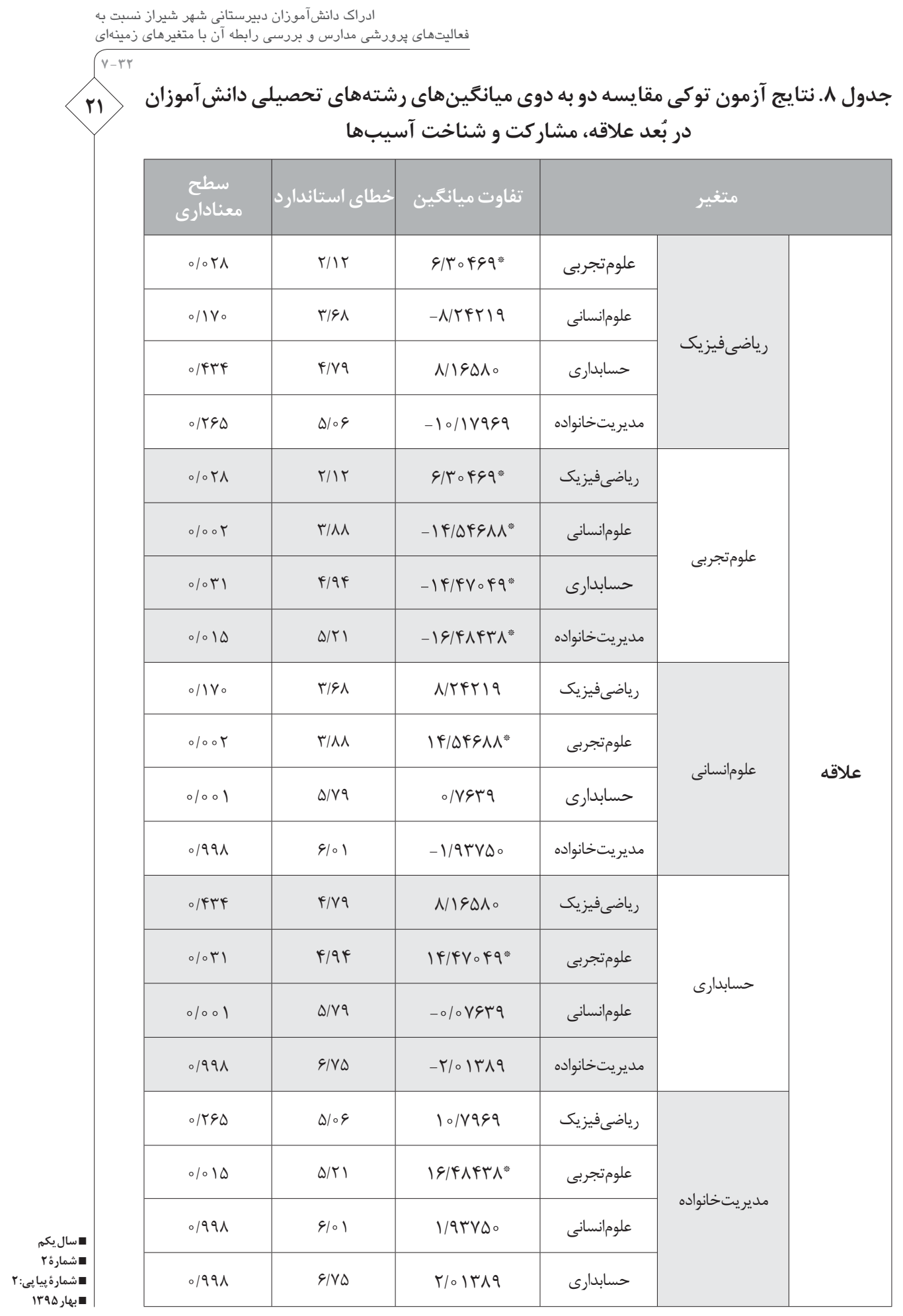




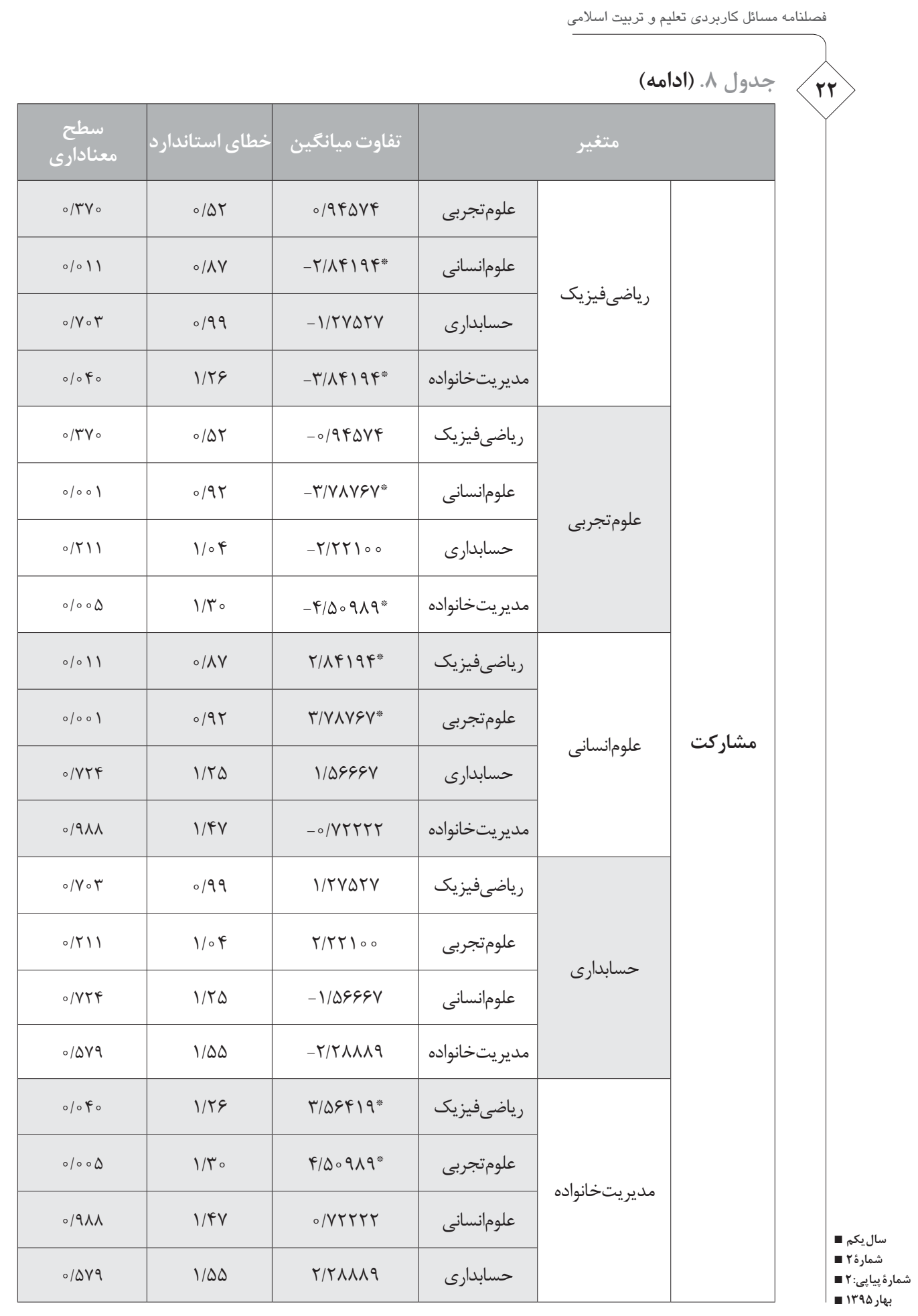




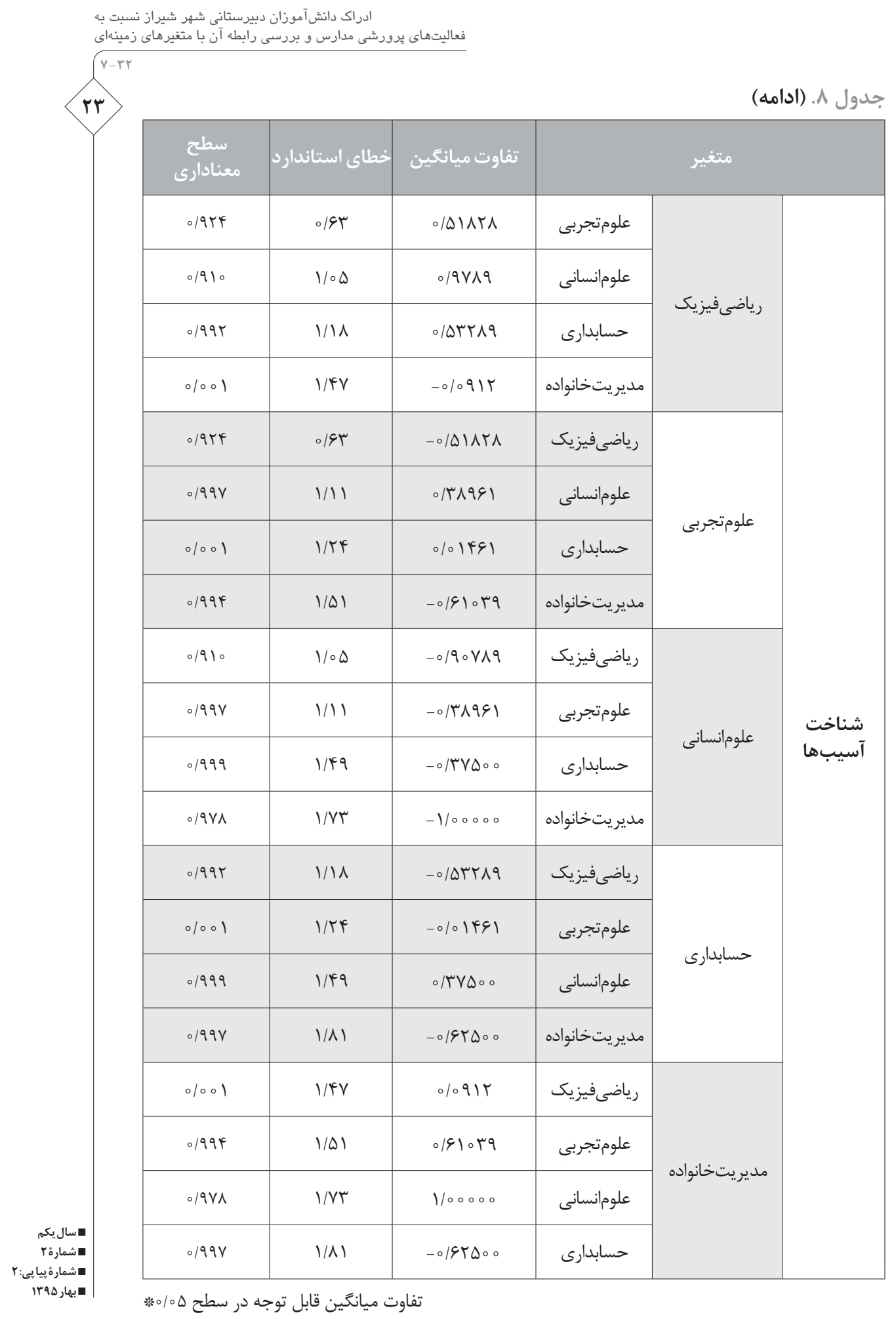


تحليل دادههاى جدول ^ حاكى از اين است كه در بُعد علاقه بين دانش آموزان رشتهُ علوم تجربى با ساير رشتهها تفاوت معنادارى مشاهده مى شود بلهطورى كه بين دانش آموز آنان رشتهٔ علومتجربى و رياضى فيزيك در سطح ب\% \%، علومتجربى و علومانسانى در سطح

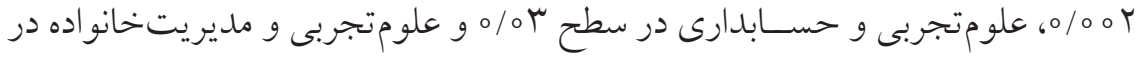

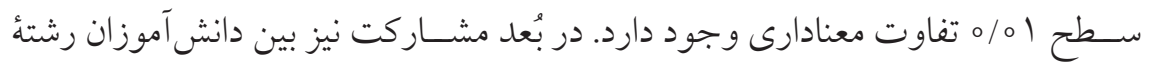

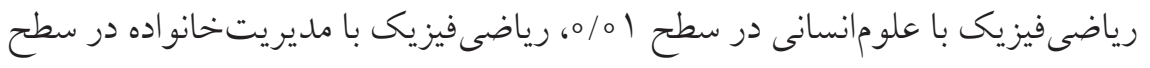

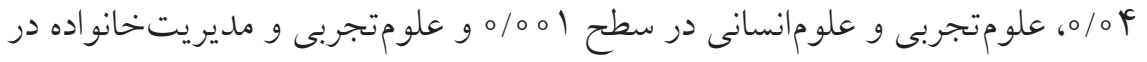

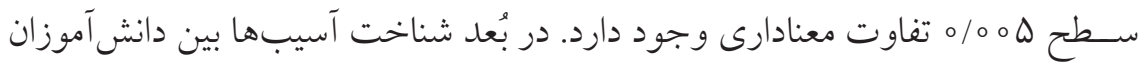

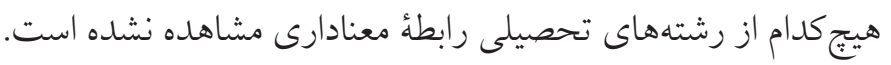

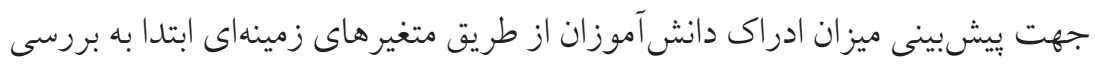

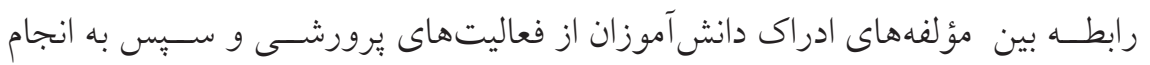

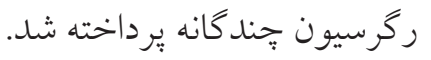
جدول 9. ماتريس همبستكَى بين متغيرهاى يزوهش

\begin{tabular}{|c|c|c|c|c|c|c|}
\hline تحصيلى & تحصيلى رشته & جنسيت & آسيبها & مشاركت & علاقه & متغير \\
\hline - & - & - & - & - & 1 & علاقه \\
\hline- & - & - & - & 1 & $0 / 49^{\text {ma }}$ & مشاركت \\
\hline - & - & - & 1 & 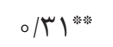 & $-0 / 1 r^{\prime \prime}$ & شناخت آسيبها \\
\hline- & - & 1 & 0109 & $-0 / 11$ & $-0 / 0 F$ & جنسيت \\
\hline - & 1 & $\circ / \Delta \cdots$ & $-0 \% \mathrm{r}$ & $0 / 19 "$ & $0 / 1 \theta^{*}$ & رشته تحصيلى \\
\hline 1 & $\circ / \Upsilon^{* * *}$ & $-0 / 1 r^{*}$ & $\circ / 1 Q^{*}$ & 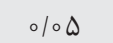 & $-0 / q^{\circ}$ & بايه تحصيلي \\
\hline
\end{tabular}

تحليـل دادههــاى جدول 9 حاكى از اين اســت كه بين جنسـيت و ابعـاد ادراى دانشآموزان از فعاليتهاى يرورشى ارتباط معنادارى وجود ندارد. بين رشته تحصيلى و واده

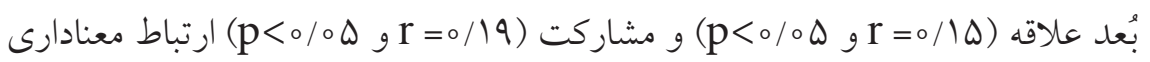

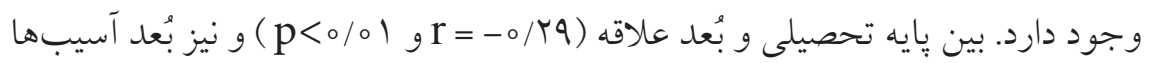

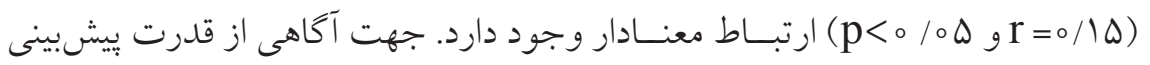




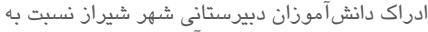

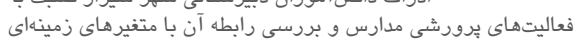

متغيرهاى زمينهاى بر متغير وابسته از تحليل ركرسيون هِند متغيره استفاده شد كه نتايج آن در جدول ما كزارش شده است.

جدول •ا. نتايج رَّرسـيون جند متغيرة ادراك دانشى آموزان از فعاليتهاى يرورشى (علاقه،

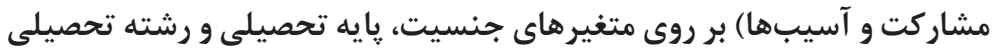

\begin{tabular}{|c|c|c|c|c|c|c|}
\hline \multirow{2}{*}{ معادارى سطح } & \multirow{2}{*}{$t$} & \multirow{2}{*}{ استاند|رد شله إب } & \multicolumn{2}{|c|}{ استاندارئ نشله } & \multirow{2}{*}{ مستغيرهاى } & \multirow{2}{*}{ وتغيرهاى } \\
\hline & & & خطاندار & B & & \\
\hline o|q1Y & $\circ / \Delta \circ \Lambda$ & ס & $r / 0 q F$ & $1 / 04 q$ & جنسيت & \multirow{3}{*}{ علاقه } \\
\hline 010001 & $-910 \% \circ$ & $-0 / 4 \circ 9$ & $r / r \Delta q$ & -1 H/GFa & پايئٌ تحصيلى & \\
\hline 010001 & $F / \backslash \wedge \gamma$ & $\circ / 419$ & $1 / 099$ & $f / \Delta \wedge q$ & رشتهٔ تحصيلى & \\
\hline$\circ / \Delta \Delta \Lambda$ & $-0 / 0 \wedge \varphi$ & $-0 / 041$ & o/dra & سוץ/י- & جنسيت & \multirow{3}{*}{ مشاركت } \\
\hline$\circ / \Lambda \circ \circ$ & $-0 / T \Delta T$ & $-0 / 01 \mathrm{~V}$ & - DQY & $-.1 \mathrm{kr}$ & پايئ تحصيلى & \\
\hline $0 / 0 T_{1}$ & T/TIF & $\circ / I V D$ & o/TVV & olgFt & رشتأ تحصيلى & \\
\hline$\circ / T V 。$ & $\circ / 199$ & o/. & - IGTS & - LDST & جنسيت & \multirow{3}{*}{ شناخت } \\
\hline$\circ / 0 \circ \wedge$ & $r / 9 \wedge \Delta$ & ०/IVG & .1990 & I/VAৎ & پايئ تحصيلى & \\
\hline o/TIV & -1/00 & ००VG & $0 / 419$ & $-0 / \mu r \circ$ & رشتأ تحصيلى & \\
\hline
\end{tabular}

تحليل دادهاى جدول ما احاكى از اين اسـت كه علىرغم وجود تفاوت، نمىتوان

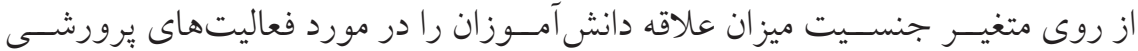

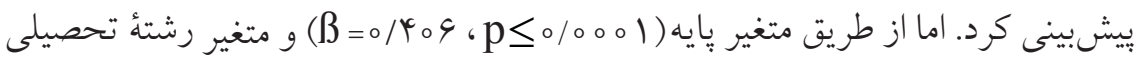

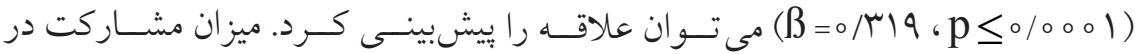

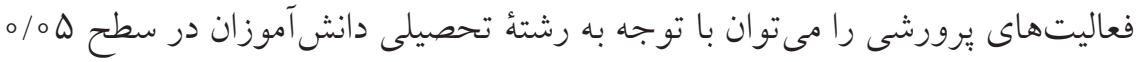

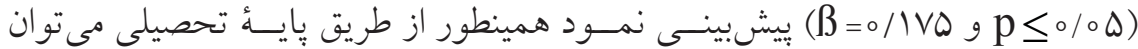

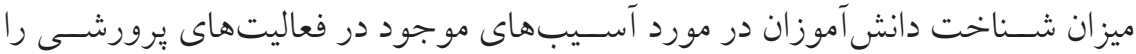

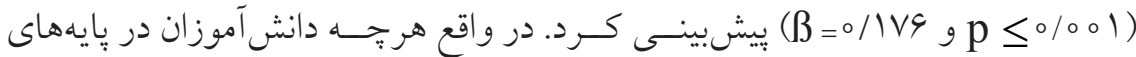
تحصيلى بالاترى قرار گيرند، قادر به شـناخت بيشـتر آسـيبـها در حوزه فعاليتهاى

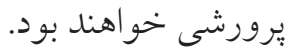




\section{بحث و نتيجه كَيرى}

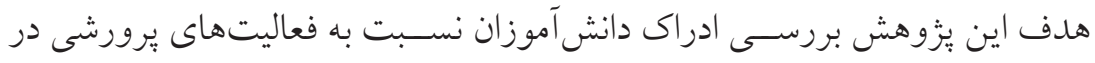

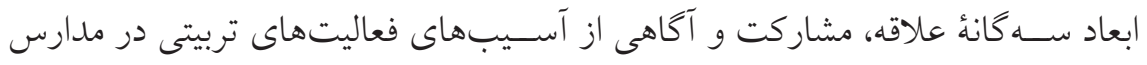

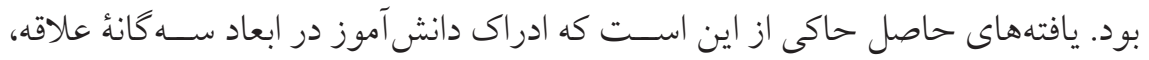

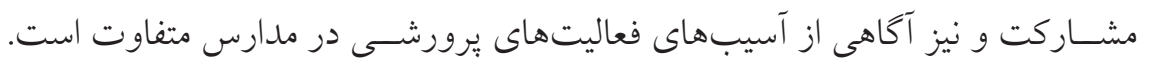

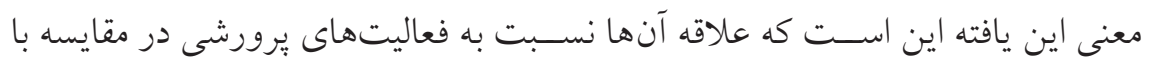

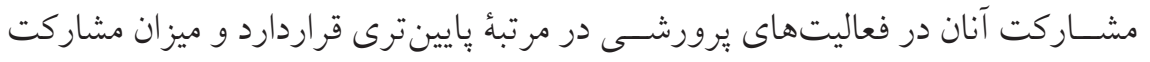

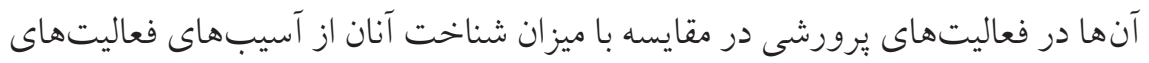

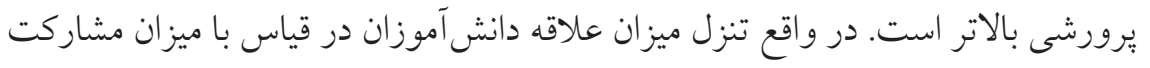

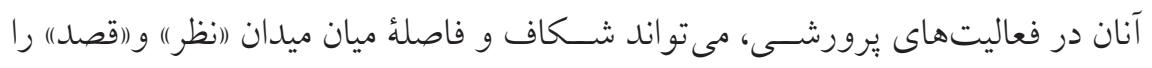

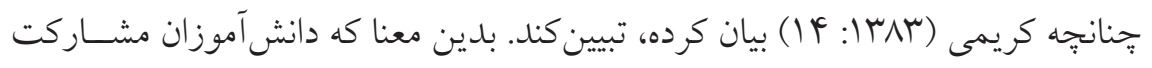

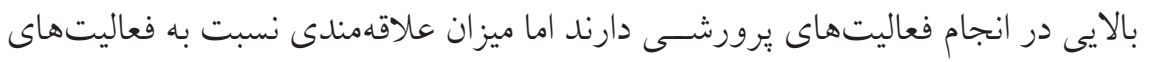

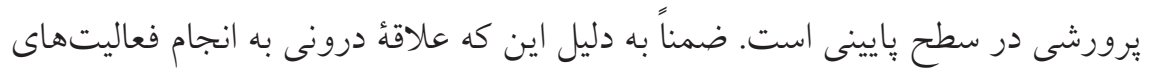

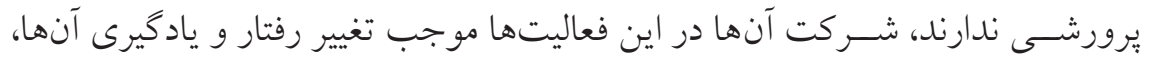

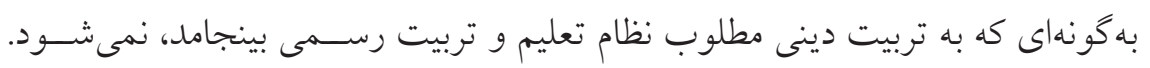

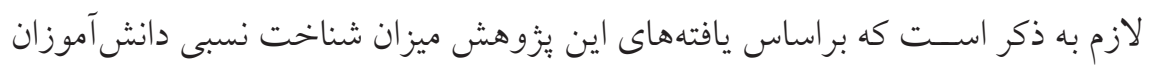

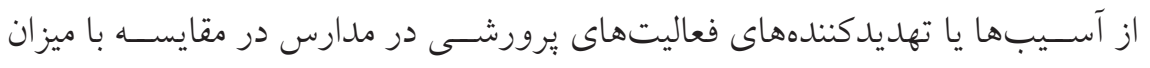

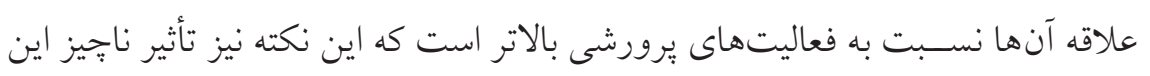

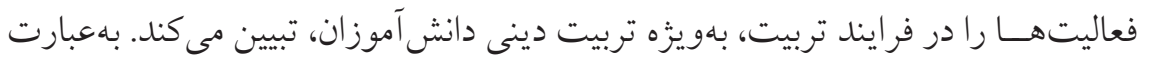

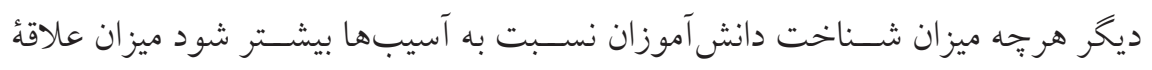

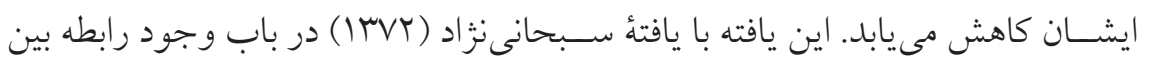

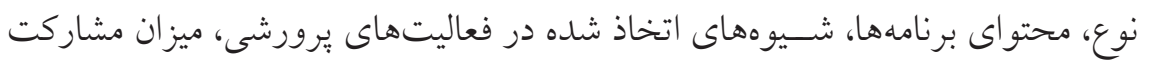

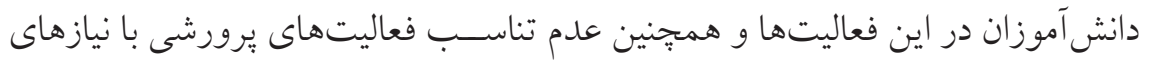

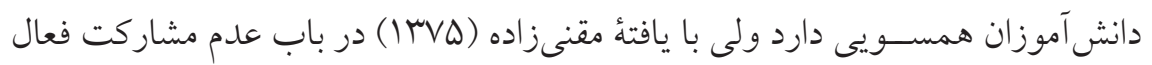

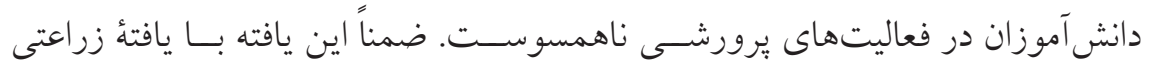

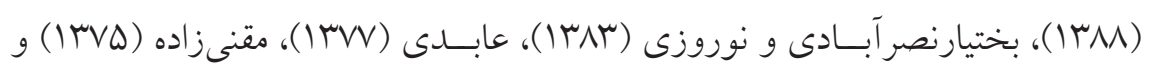

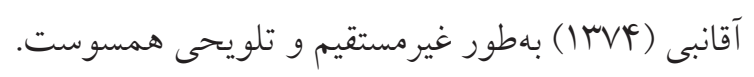




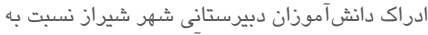

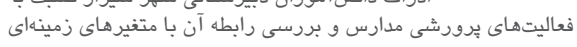

ديخـــر يافته اين بززوهـش مربوط به ارتباط بيــن ادراك دانش آموزان از فعاليتهاى

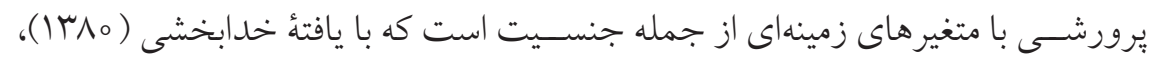

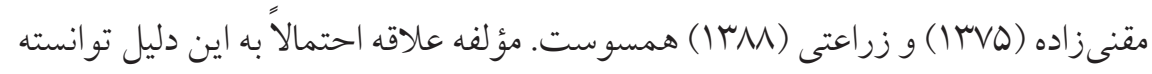

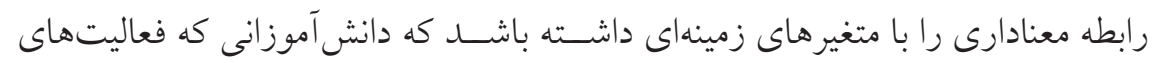

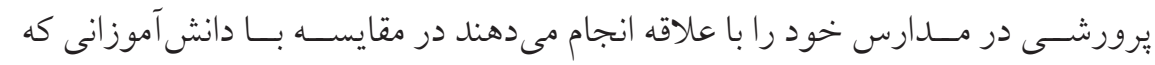

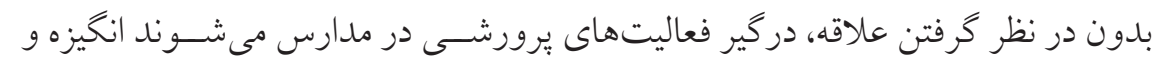

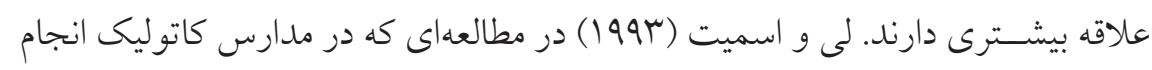

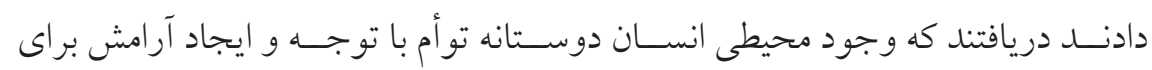

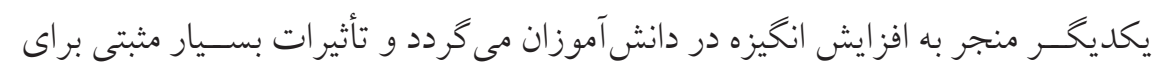

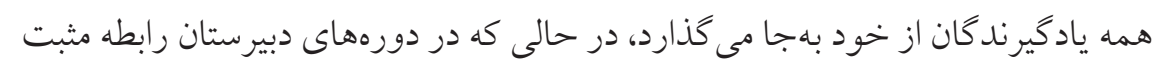
توأم با مهر معلم و مربى كاهش مى يابد و اين تغيير در نوع رابطه، كاسته شدن از از انخيزه

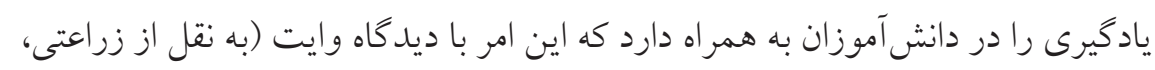

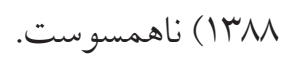
ديخر يافتهُ اين يزوهش مربوط به رابطه بين ويائُ تحصيلى و همينطور رشتهُ تحصيلى

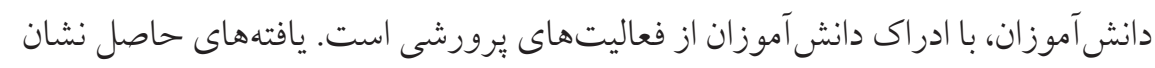

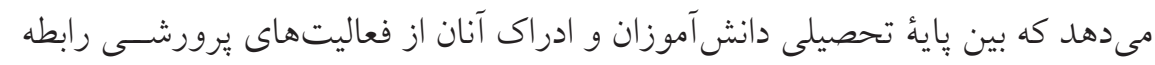

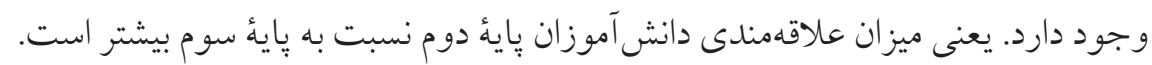

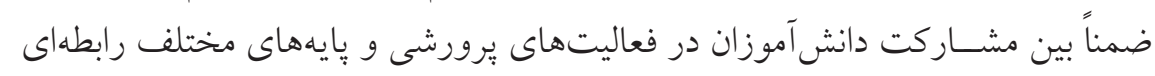

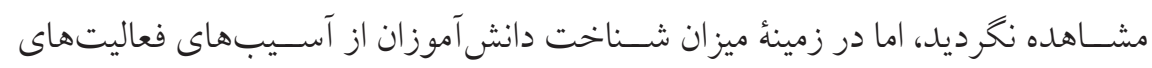

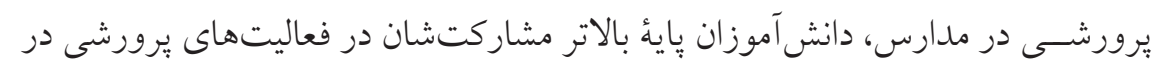

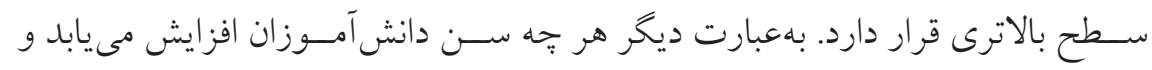

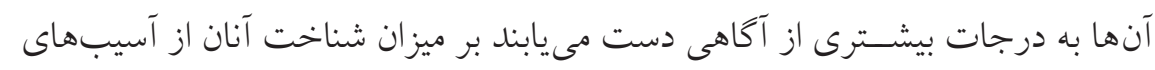

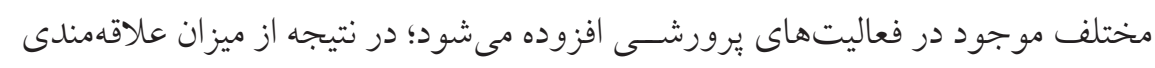

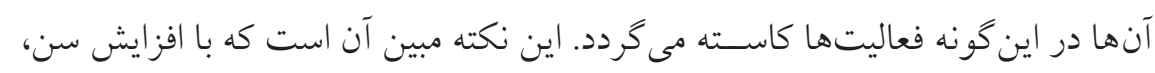

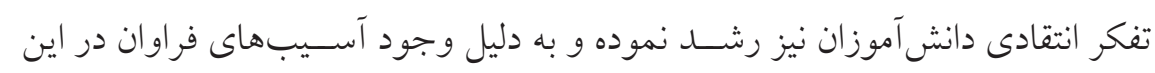

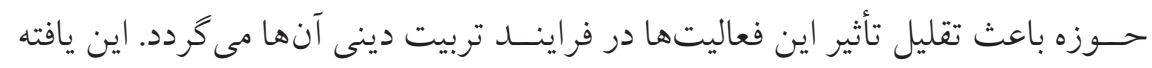

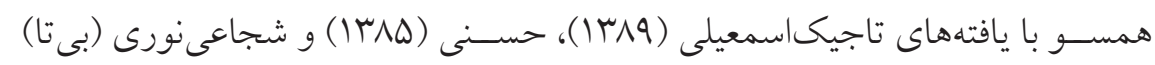


اســت. البته وجود رابطه بين افزايش آكاهى از آســيبهاى فعاليتهاى برورشى و بالا

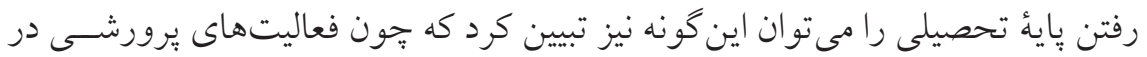

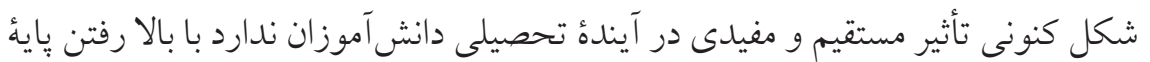

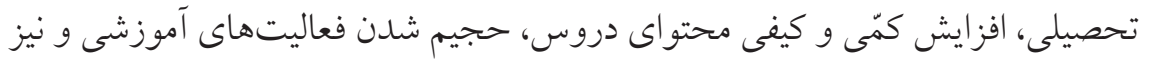

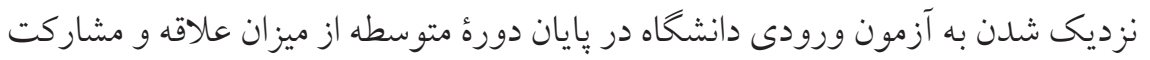
دانش آموزان نسبت به فعاليتهاى برورشى كاسته مى گرددد.

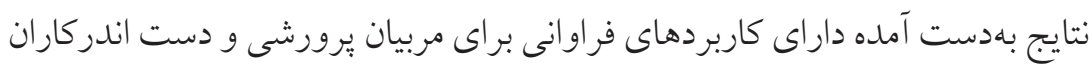

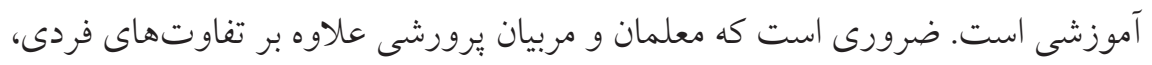

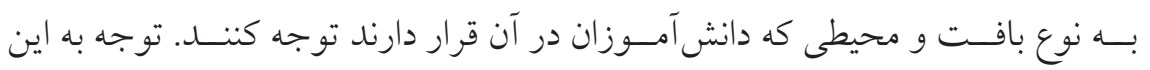

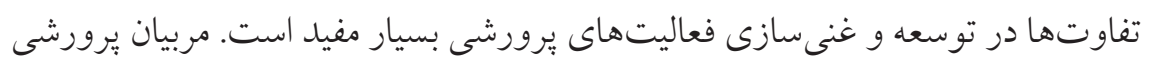

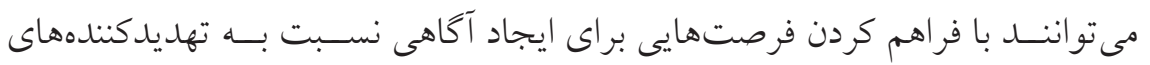
فعاليتهاى يرورشى، در افزايش علاقه و مشاركت دانش آموزان نقش مهمى برى ايفا نمايند.

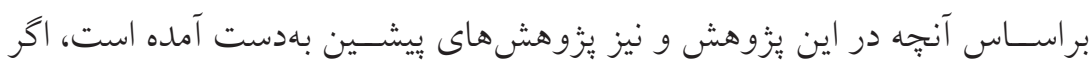

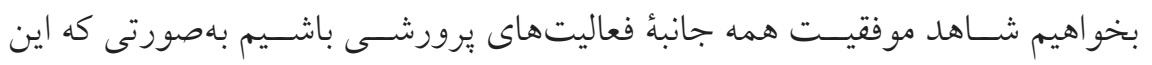

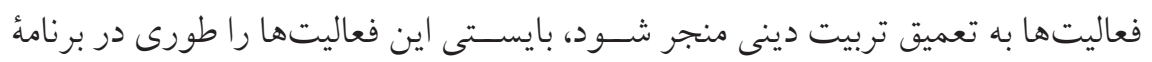

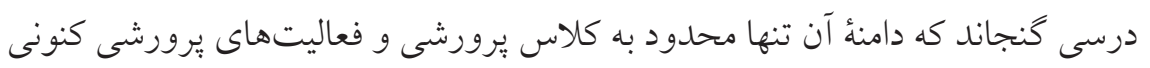

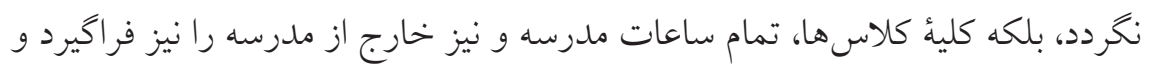

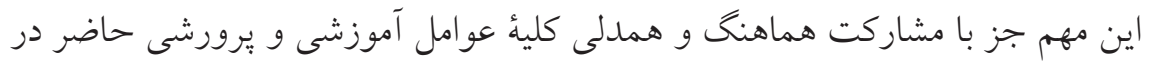
مدرسه محقق نمى گردد. علاوه بر اين يافتههاى حاصل نشان داد كه هر جهه ميزان شناخت دانش آموز دان نسبت

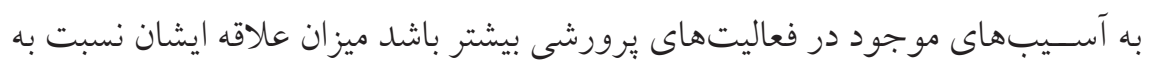

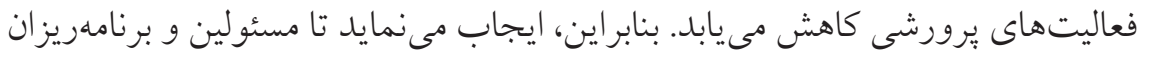

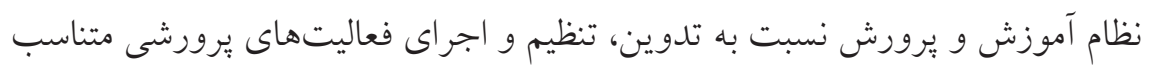

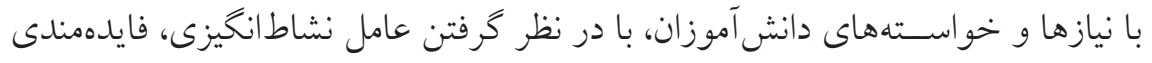

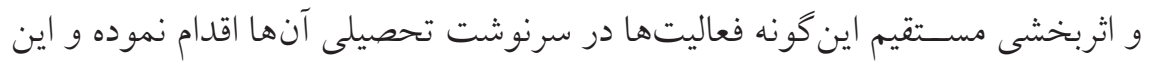

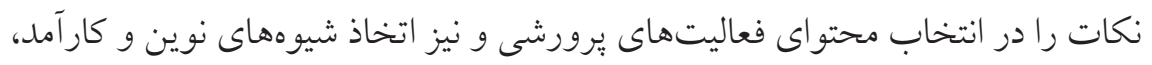

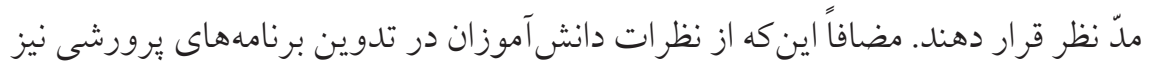




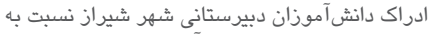

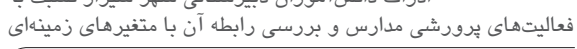

بهرهبردارى شود. بنابر اين باز آموزى مستمر مربيان برورشى و تجديد نظر در برنامههاى

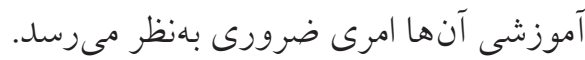

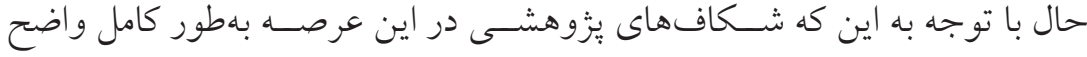

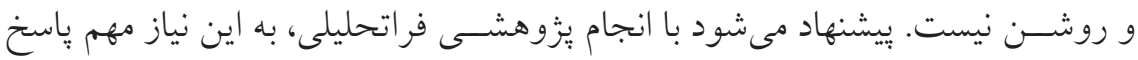

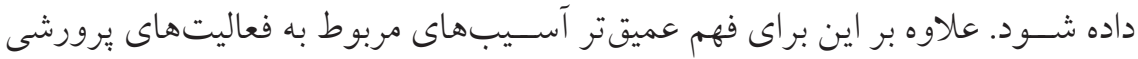

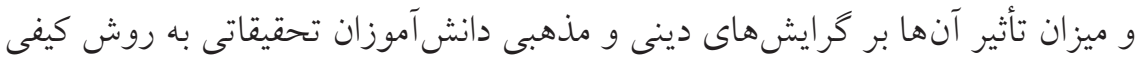

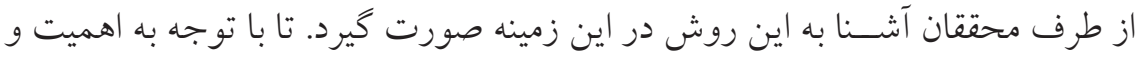
جايخاه خاص تربيت دينى در نظام تعليم و تربيت جمهورى اسـلامى ايران، با استفاده

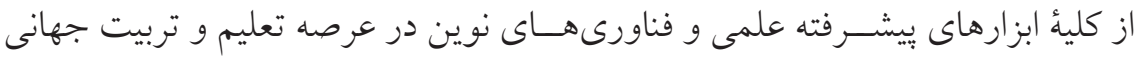
از ييشرفتهترين روشهاى آموزشى براى رشد دانش مذهبى و بينش دينى دانش آموزان | استفاده كردد.

علاوه بر اين لازم است مربيان برورشى به لحاظ سطح تحصيلات و سابقه از نيروهاى

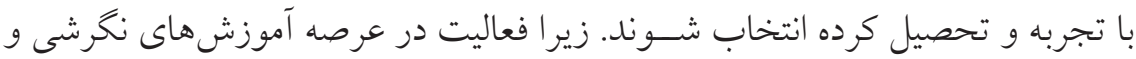
عاطفى، به مراتب از عرصه آموزشهاى شــناختى حساستر، مهمتر و سرنوشت سازتر است.

آشــنايى مربيان برورشسى مدارس با مؤلفههاى اساسـى طراحى و اجراى مطلوب فعاليتهاى برورشـى در قالب مشـاركتى مىتو اند به نحو فوق العادهاى در موفقيت و و

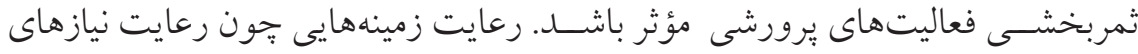

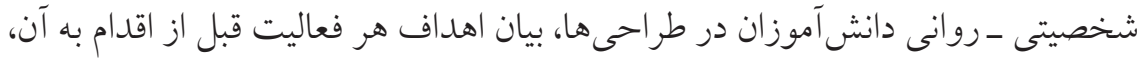

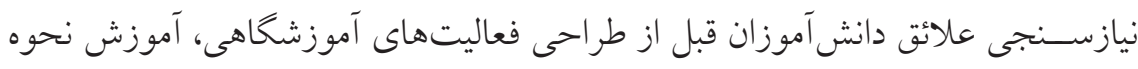

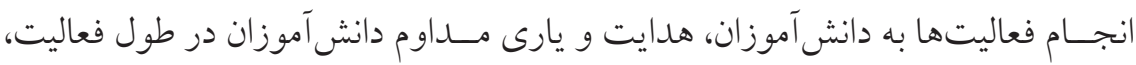

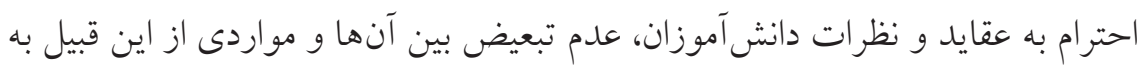

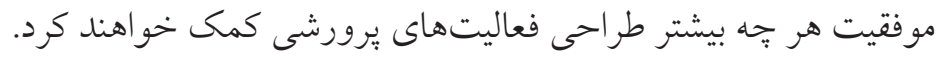

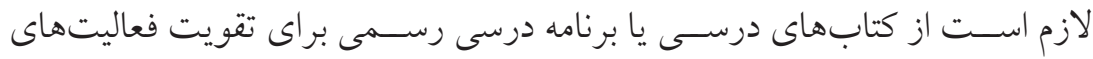

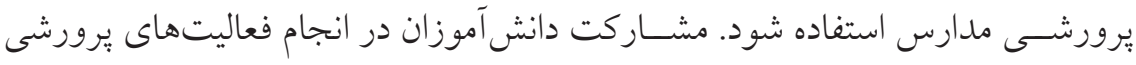

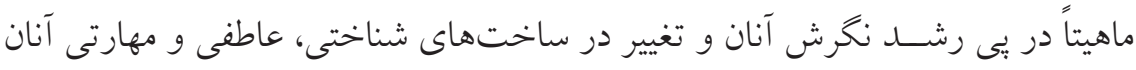

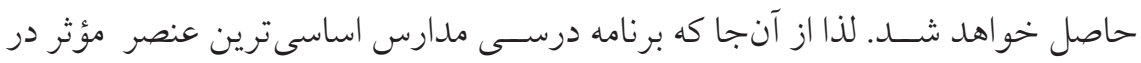


اين زمينه مىباشـــ لازم اسـت ضمن تحول در رويكرد رفتارى و خطى حاكم بر نظام برنامهريزى درسى كشور، برنامهُ درسى به كتاب درسى و مجموعهاى از مطالب شناختى

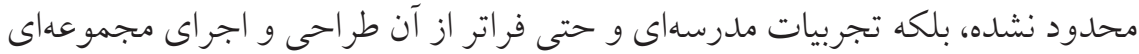
از فرصتهاى عملى و مشاركتى در صحنه جامعه نيز براى دانش آموزان را در بر گيرد.

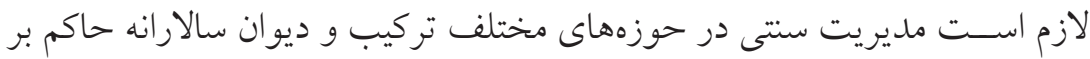

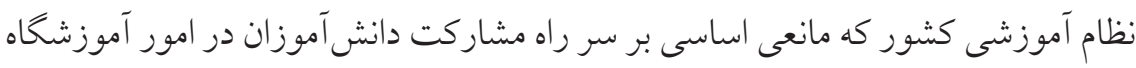
است به سمت سبك و ساختارهاى نوين مديريتى و از جمله مديريت مشاركتى تحول

از محدوديتهاى اين يزوهش، استفاده از ابزارهاى خودخزارشدههى است. استفاده

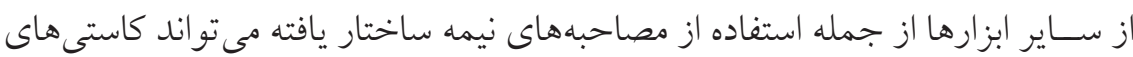

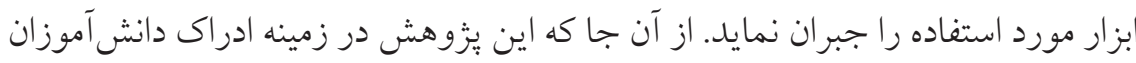

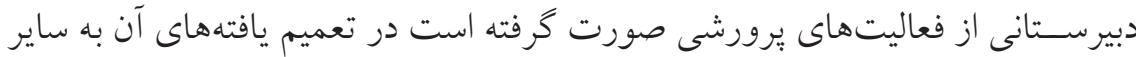
دورههاى تحصيلى بايد تأمل نمود. 


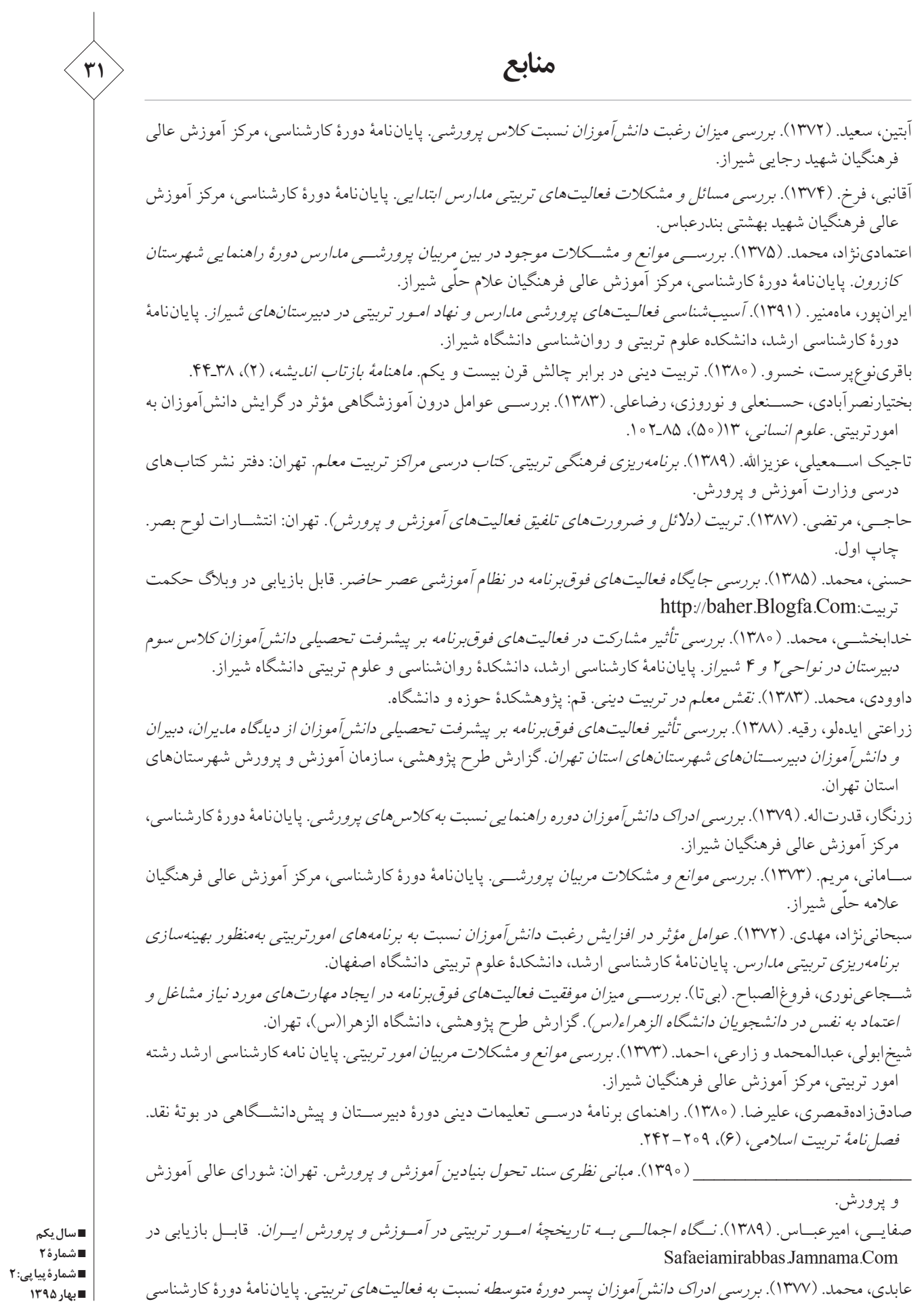




$$
\begin{aligned}
& \text { فصلنامه مسائل كاربردى تعليم و تربيت اسلامى } \\
& \text { در رشته امور تربيتى. مركز آموزش عالى فرهنخيان شيراز. }
\end{aligned}
$$

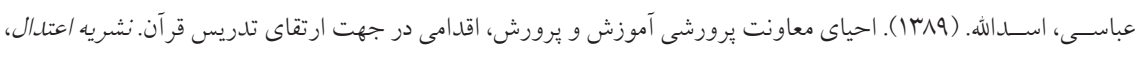

$$
\begin{aligned}
& 19 / 4 / \pi q
\end{aligned}
$$

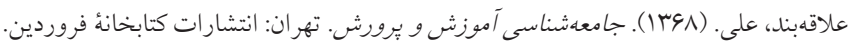

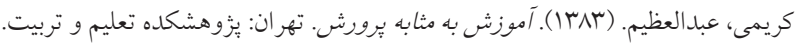

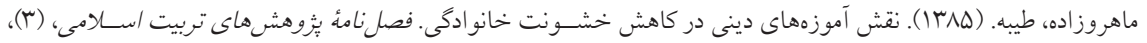

$$
\begin{aligned}
& \text {. }
\end{aligned}
$$

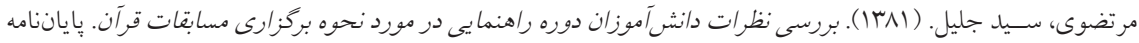

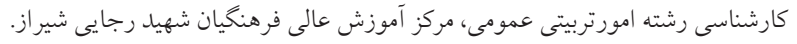

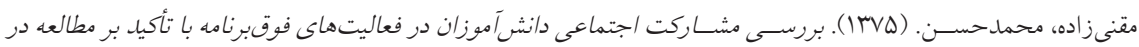

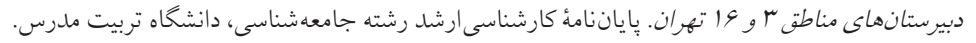

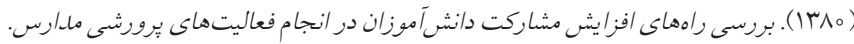

$$
\begin{aligned}
& \text { مركز آموزش عالى امام خمينى (ره) كرج. }
\end{aligned}
$$

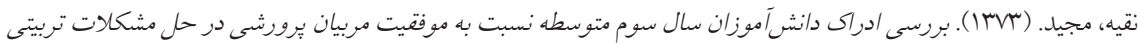

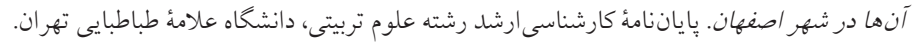

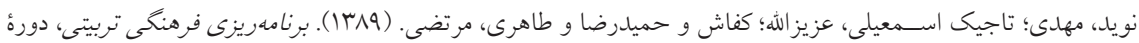

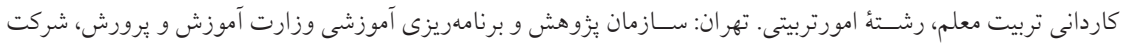

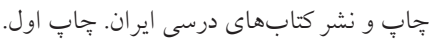

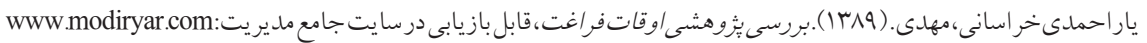

Adelman, H. S., \& Taylor, L. (1997).Addressing barriers to learning: Beyond school-linked service and fullservice schools. American Journal of Orthopsychiatry, 67(3), 408-421.

Eccles, J. S., \& Roeser, R. W. (2011).Schools as developmental contexts during adolescence. Journal of Research on Adolescence, 21(1), 225-241.

Finn, J. D. (1993). School engagement and students at risk. Washington, DC: National Center for Educational Statistics, U. S. Department of Education. Available at www.nces.Ed.gov/pubsearch/pubsinfo. Asp? Pubid $=93470$.

Gentry, M., Gable, R. K., \& Rizza, M. G. (2002). Students' perceptions of classroom activities: Are there grade-level and gender differences? Journal of Educational Psychology, 94 (3), 539-544.

Lamborn, S. D., Brown, B. B., Mounts, N. S., \& Steinberg, L. (1992). Putting school in perspective: The influence of family, peers, extracurricular participation, and part-time work on academic engagement. In F. M. Newman (Ed.), Student engagement and achievement in American secondary schools (pp. 153-191). New York: Teachers College Press.

LaRocque, L. M. (2008). Assessing perceptions of the environment in elementary classrooms: The link with achievement. Educational Psychology in Practices, 24(4), 289-305.

Lee, V. E., \& Smith, J. B. (1993). Effects of school restructuring on the achievement and engagement of middle-grade students. Sociology of Education, 66(3), 164-187.

Marsh, H. W. (1992). Extracurricular Activities: Beneficial extension of the traditional curriculum or subversion of academic goals? Journal of Educational Psychology, 84(4), 553-562.

Ryan, R. M., \& Grolnick, W. S. (1986). Origins and pawns in the classroom: Self-report and projective assessments of children's perception. Journal of Personality and Social Psychology. 50, 550-558.

Van Petegem, K., Aelterman, A., Van Keer, H., \& Rosseel, Y. (2008).The influence of student characteristics and interpersonal teacher behaviour in the classroom on student's wellbeing. Social Indicators Research, 85(2), 279-291. 